\title{
The New EU Remuneration Policy as Good but Not Desired Corporate Governance Mechanism and the Role of CSR Disclosing
}

\author{
Luis Porcuna Enguix 1,2
}

1 Department of Economics and Social Sciences, Universitat Politècnica de València, 46022 Valencia, Spain; lporeng@esp.upv.es

2 Centre for Research in Business Management (CEGEA), Universitat Politècnica de València, 46022 Valencia, Spain

Citation: Porcuna Enguix, L. The New EU Remuneration Policy as Good but Not Desired Corporate Governance Mechanism and the Role of CSR Disclosing. Sustainability 2021, 13, 5476. https://doi.org/10.3390/ su13105476

Academic Editor: María Consuelo Pucheta-Martínez

Received: 11 April 2021

Accepted: 11 May 2021

Published: 13 May 2021

Publisher's Note: MDPI stays neutral with regard to jurisdictional claims in published maps and institutional affiliations.

Copyright: (C) 2021 by the author. Licensee MDPI, Basel, Switzerland. This article is an open access article distributed under the terms and conditions of the Creative Commons Attribution (CC BY) license (https:/ / creativecommons.org/licenses/by/ $4.0 /)$.
Abstract: The recent global financial crisis (GFC) has put under scrutiny the sound remuneration policy and consequently the incentives design that influences risk-taking by managers in the banking industry to be a politically charged variable. In particular, this paper analyzes the new EU remuneration regulation of bank executive compensation and the role of corporate social responsibility (CSR) on this. Though all the EU efforts put into remuneration practices suggest commitment in aligning risk, performance, and compensation and aim at easing bank managers' risk appetite for variable payments, the new regulation might drive unintended consequences, creating adverse selection problems in EU banks and hidden compensation habits that lower transparency, thus threatening financial system's sustainability. Focusing on European Banking Authority (EBA) reports spanning from 2010 to 2017, the data reveals increasing values on the fixed component, less involvement in bank discipline by economic agents, and a potential for accounting-based incentives compensation that might reinforce attitudes towards building countercyclical buffers and smoothing earnings. As well, the new regulation might reduce the number of best-performing bank managers in the Eurozone, since "bad risks" are accepted to the detriment of "good risks," which might stimulate their migration. In contrast, CSR investment is supposed to offset such practices and incentives that harm EU financial stability. As a result, policymakers, banks, and regulators should promote the transparency of CSR disclosure.

Keywords: remuneration policy; bank compensation; corporate governance; incentives; CSR disclosure

\section{Introduction}

Despite all the attempts to figure out the precise factors that contributed to the recent global financial crisis (GFC), the answer is still inconclusive but firm in some elements. One of these parts was the restatement of the global corporate governance (CG) principles of financial firms presupposing that governance failures were heavily responsible for these institutions' deficiencies during the GFC [1]. In particular, sound remuneration policies in banks were fundamentally the focus of the controversy because bank compensation is a politically charged variable and the amounts usually exceed what is considered normal for the rest; therefore, stakeholders overall and the general public in particular (especially voters) seem to be more involved and thus interested in such governance faced during downturns. The point is that people believe that the variable portion of total remuneration rewarded greed and, in the end, failure [2]. Accordingly, the GFC has absolutely put under severe scrutiny remuneration policy and consequently the incentives design that affects risk-taking by managers in the banking industry [3], influencing the sustainability of its operating practices. One may discover studies that discuss the relation between the GFC and the remuneration policy, e.g., [4-7]; however, the existing empirical evidence is limited [8,9] and sometimes contradictory to the general opinion [10]. Nevertheless, 
investors, supervisors, regulators, and even politicians have been discussing the level and structures of compensation plans that appeared to exacerbate risk-taking and inspire short-termism. So as to shirk another financial collapse, the European Union (EU) approved and issued several regulations for remuneration requirements in CDR III [11-13]. Though all the EU efforts put into remuneration practices suggest commitment in the sense of aligning risk, performance, and remuneration to reduce excessive risk-taking in banks, good does not necessarily imply desirable. In fact, due to all the unintended consequences of such compensation rules, the word "flexibility" has been recently incorporated into the regulation [14], Whereas 8 , maybe to cover its back.

Many are the changes that have been produced over time and thus implemented into the EU remuneration policies to avoid excessive risk-taking in banks. Among all the reforms, we can highlight two main compensation mechanisms aimed at easing bank managers' risk appetite for variable payments. Firstly, mechanisms that rely on instruments and longer deferrals, including retention periods such as malus and clawback; and secondly, limiting the variable compensation (the bonus cap). Accordingly, I postulate that in doing so, the regulations might exacerbate moral hazard problems, generate more information asymmetries, and create "hidden" compensation practices that lower transparency and accelerate the disinterest of bank managers and owners when their banks fail. Maybe, instead of balancing profit and risk to avoid excessive risk-taking not aligned with business strategy, it creates unsustainable profits that might harm the economic and social sustainability of society.

Among other factors to recover banks' reputation, some authors argue that outcomes of CSR reporting should be especially notorious in the banking sector, e.g., [15]. Several reasons explain such interest [16]. First, transparency, corporate accountability, and public trust need to be recovered from the last GFC. Hence, due to their importance in the whole economy, banks are called on to have broader moral responsibility. Second, as a result of the aforementioned, banks are supposed to be accountable to other stakeholders (creditors, borrowers, government, supervisors, regulators, employees, etc.). Financial firms must be fairly responsive to all their demands and ensure that bank corporate practices are aligned with broader societal interests [17]. As a benefit of the CSR initiative by banks, we can highlight that CSR reinforces bank operations' legitimacy [18], facilitates due diligence and evaluation [19,20], reduces information asymmetries [21], enhances financial conditions and credit rating [22], and improves compliance, thereby reducing internal costs [23]. CSR actions are expected to affect compensation schemes. If CSR improves banks' performance, remuneration plans are likely to be structured more transparently and will contemplate a longer time frame, which reduces risk appetite from managers-an "insurance-like" effect [24] -and accounting-based incentives compensation. Nevertheless, reputational and economic effects from such practices will always be confronted, so achieving the optimal level of CSR would not penalize good CG strategies and would avoid conflicts of interest [25]. Accordingly, I postulate that encouraging banks to engage more in CSR practices would probably automatically rectify or balance potential problems coming from remuneration schemes.

The aim of this study is not only to show the impact of the new EU remuneration policy on bank executives' compensation incentives, but also to unravel the origin and backstage of these new EU remuneration rules, as well as critically examine the impact of the CSR initiative on bank CEO compensation.

For that purpose, the research methodology is as follows. I focus attention on the main bank material risk takers (MRTs, or identified staff) to be visible bank head managers who must play different roles to bring order in the riskiness that governs the banking industry. The data from the EBA reports [26-33] spanning from 2010 to 2017 was collected because it provides remuneration practices of the higher earners (HEs-those that earn more than EUR 1 million a year) in the EU banking industry. Once collected, we graphically saw a tendency that comes to confirm the previous postulations. The results show certain trends that came to evidence perverse incentives to discretion. Moreover, as the institutional theory 
states, the context strongly influences governance and then executive remuneration [34], and this was seen by comparing the UK with the rest of EU. Overall, we appreciated an abrupt growth in HEs, especially from 2013 to 2015 (61.8\% in general, and 135\% for the identified staff); a great proportion of $\mathrm{HE}$ and identified staff arose from the UK (80\%). The overall variable-to-fixed ratio experienced a significative reduction of $168 \%$, but was accomplished in terms of deferrals. We also noticed that the UK bank managers will be the most affected by the remuneration guidelines (at the time they will probably leave the EU) since HEs from the UK are the most paid in the EU. In addition, we also observed that EU bank remuneration substantially but dangerously favored fixed pay over the variable component. On average, each HE increased their fixed pay to the detriment of variable pay; however, with the exception of the UK, the main remuneration components completely turned their position. That is, the fixed part surpassed variable pay. All these points denote clear preferences and herding behavior by HEs from the UK to stay in their country and a potential migration of EU best-performing bank managers to the UK when Brexit is fulfilled. In addition, we argue that CSR practices might solve most of the questionable and controversial negative effects of the new EU remuneration rules as long as bank managers partially resign to economic aspects and opt for social reputation.

The contribution of this paper is twofold. Firstly, having a restrictive cap on executive bonuses (which is defined as having above-market salaries and high but capped bonus opportunities), more complex remuneration schemes, and risk management assessment may lead to perverse incentives by bank managers that might threaten the financial system's sustainability: (i) increasing the fixed component; (ii) less involvement in bank discipline by economic agents; (iii) boosting earnings management, and income smoothing practices in particular, since they create incentives to accept "bad risks" and reject "good risks" (when a bank manager reaches the bonus cap, additional efforts are not compensated anymore, so they tend to transfer actual realized profits into subsequent periods-this idea is somehow associated with financial fraud and earnings quality. For further information and reasoning about earnings quality, see [35-38], among others); and finally, (iv) intensifying adverse selection problems (the EU scenario would be only attractive for bad-performing bank managers and would have negative repercussions on bank competitiveness, whereas good performers would move to other countries where their efforts are not regulated downwards). In contrast, CSR strategies would reduce cash-based compensation and information asymmetries, would disincentivize discretionary practices that partly impair financial transparency and thus stability, and would retain high-quality employees.

Secondly, the unintended consequences of the new EU remuneration policies may be direct consequences of having made decisions in an inappropriate way, and several arguments come to light. First, competing and traditional theories in explaining bank executives' remuneration are not fully successful. For instance, just resolving principalagent conflict is not enough, because risk-taking by bank managers has important social costs, and maybe the "inside debt" can be more adequate than maximizing shareholders' value [39]. Another example is that the unequal bargaining power between the board of directors and executives is not taken into account [40]. Either the "salary fan" is considered or losses are more meaningful than gains if they are equal [41]. Second, longer deferral rules better align the risk horizons of decisive individuals with long-term safety and soundness, but this ruling should not ignore that they are much shorter than the estimated length of the credit cycle of banks ( 8 to 30 years on average). Third, government intervention in corporate governance policies, especially in remuneration structure, is one of the main drivers [42]. We must not forget that the Financial Stability Board (FSB) and prudential organism are composed of politicians and bank supervisors who seek to guarantee the financial stability of the system. In order to avoid potential bailouts (that they have to face for sure if systemic banks fail), they allow or partly encourage bank managers to engage in excessive risktaking [3] or even use accounting choices to smooth income (e.g., via loan loss impairments), which results in a false stability to the detriment of financial transparency [43]. For better or worse, but interestingly, politicians and prudential regulators have not responded yet with 
more binding remuneration regulations to the actual evidence of the existing weakness in the banking sector across the EU [44], in spite of the introduction of the stringent bonus cap. Instead, policymakers, banks, and regulators should also promote the transparency of CSR disclosures [17,45].

The remainder of this paper is structured as follows. Section 2 introduces the reader to CEO compensation and the role of CSR in banks. Section 3 explains in more detail EU bank remuneration policies. Section 4 explores the idea that accounting-based incentives compensation is likely to reinforce attitudes towards building countercyclical buffers and manage earnings, which includes income-smoothing behaviors. In turn, CSR investment may reduce such discretion. Section 5 presents the unintended consequences derived from the new EU remuneration policies, and (numerical and CSR) actions to circumvent the EBA guidelines. Finally, Section 6 concludes the paper.

\section{CEO Compensation in Banks}

\subsection{Types of Executive Remuneration}

We all are aware that the degree of compensation amounts varies across companies, which is completely understandable because it depends on how capable firms are of facing it. However, employees' remuneration packages (especially from the CEO perspective) traditionally encompass two elements: fixed and variable remuneration [46], as shown in Figure 1.

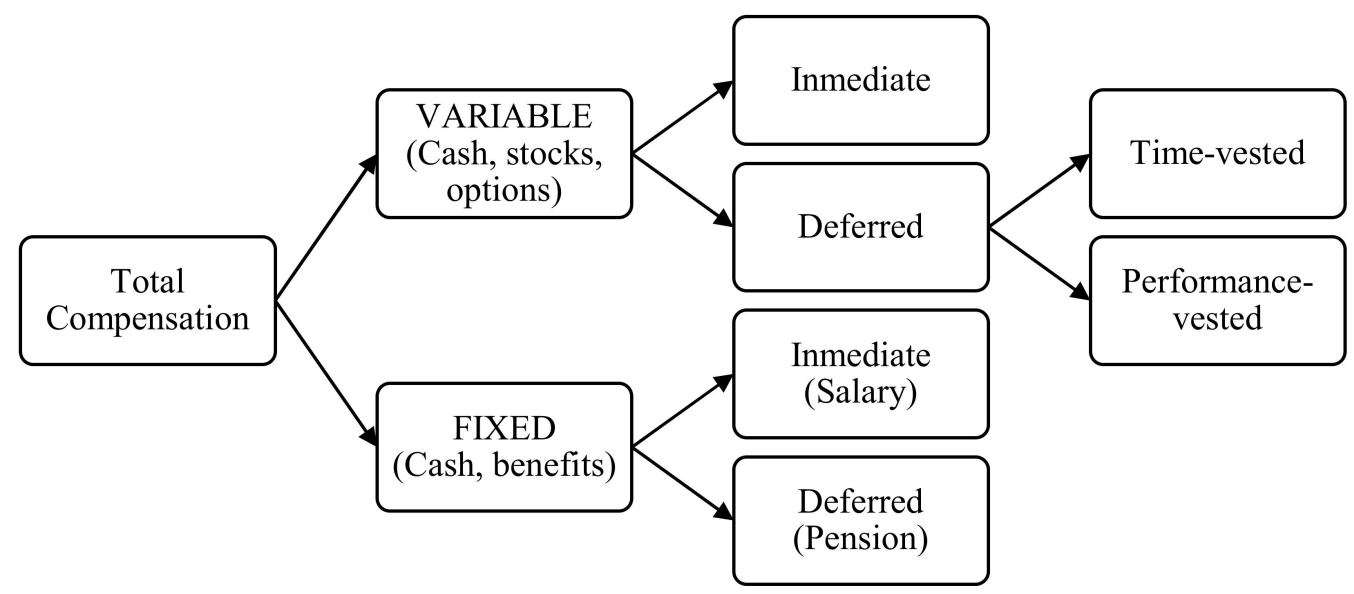

Figure 1. The composition of the total compensation package.

Fixed remuneration is commonly defined as the contracted and fixed-in-advance amount of money based on the employee's general responsibility level, position, and professional experience in the firm. This component represents an important chunk of the compensation setting procedure, as the level of other components of the remuneration are weighted relative to it [47]. As well, fixed remuneration can be paid out immediately through cash (salary) and/or deferred payments in the future (pensions). Even though these payments shall be fair and competitive but not leading in the market, the amount of fixed salary within remuneration packages eventually becomes higher mainly due to the restriction on bonus segments.

Variable remuneration is a cash award that is either paid out immediately (a form of short-term compensation) or in the future, which is called a deferred bonus. This bonus payment is always weighted as a function of both performance targets, which includes accounting and share-based measures regarding industry benchmarking, and a restrictive "cap" above which it cannot go. The period comprised between granting it and paying it out is known as a vested period, nomenclature that holds for the rest variable components.

Firms are also allowed to pay bonus compensation in non-cash awards in the form of stocks and options. In practice, CEO compensation options retain a "call" property, giving the owner the right (but not the requirement) to buy the underlying stock, which 
is usually exercised on the money. At the end, stock options are preconceived to tie their pay to the company long-term performance, applying a forward-looking performance measure (e.g., stock price). In addition, bonus payment via stocks is another form of variable compensation (restricted share plans). The same idea for options also applies to stocks, but the payment defers for an even longer period.

In the academic and professional fields, compensation packages can be mainly split into two groups, where fixed remuneration together with bonus payments in cash awards refers to cash compensation, and the variable components in form of stocks and options allude to equity compensation. In addition to that, CEOs can also obtain bonus payments via what is labeled as "other benefits" or "benefits-in-kind," such as mobile phone bills, lunches, insurance, company cars, etc. Beyond these simple items, "welcome awards" and "severance payments" fall under the same division. On the one hand, welcome awards ("golden hello") are frequently given when the attraction of a CEO to a new company is difficult or because the CEO has incentives to continue in the old one (unvested compensation). On the other hand, severance payments ("golden parachute" or "golden handshake") are perceived to be an extra benefit given to CEOs who are dismissed through no fault of their own, often founded on the length of time hired.

\subsection{Remuneration Basics and CSR}

Corporate governance issues in banks substantially differ from other companies for many reasons. First, banks' business models are at mercy of large bases of debt in comparison with equity, with $90 \%$ average debt in financial institutions versus $35 \%$ in nonfinancial firms $[47,48]$. This obviously passes on the conflict between equity holders and fixed claimers, since CEO incentives to boost shareholder value tend to inspire excessive risk-taking actions in indebted firms [49]. In fact, stock price rises as the volatility of assets tied by the levered firm increases [48]. Second, third parties are notably exposed, resulting from transaction costs and information asymmetries that originate in banks. Banks' liabilities primarily comprise deposits, whereas their assets are mainly loans (longer maturities). This dissimilarity in liquidity together with the fact that banks can reshape their loans risk composition more rapidly than most non-financial institutions creates hidden problems (It is well known that asset substitution is comparatively easier in banks than in non-bank corporations, and this approves more elastic risk shifting and increases agency costs between shareholders and stakeholders in general but bondholders and depositors in particular, as well as the moral hazard of managers) [50]. Latent insurances to protect bank depositors and tacit guarantees of bailouts covered by governments (if governments or central banks mostly act as insurers for the banks' assets, asking to regulate unhealthy risktaking activities would not be madness. For instance, [51] reveal that integrating incentive features on top-management compensation plans would favor bank owners to set a CEO remuneration system that preserves bank activities at a socially accepted level of risk) or central banks generate a moral hazard that encourages shareholders to engage in excessive risk-taking, thus affecting creditors, depositors, and taxpayers. Moreover, the moral hazard is aggravated when banks approach bankruptcy or insolvency because shareholders do not embody the losses from risky investments but instead the likely benefit from potential gains [3]. Last but not least, banks are more opaque and their loans composition and quality are sometimes difficult to disentangle, which complicates assessing their risk profile and stability. In addition, as mentioned before, information asymmetries restrict market discipline for creditors and depositors, which raises the moral hazard of managers at the same time.

For all these exposed reasons, among others, we must be aware that "good" corporate governance does not necessarily mean "desirable" corporate governance. That is, having "good" corporate governance instruments can indicate aligning the interests of stockholders and bank managers, which leads the latter to engage in more risky strategies. For instance, if correct incentives that shared interest were properly aligned, most of the losses stemming from bad decisions would be externalized whereas the gains would entirely be internalized. 
In this regard, traditional banking bonus structures would have provided significant penalties. How? Via bonus plans by keeping base salaries below competitive market levels [5]. However, banks' remuneration architecture works differently, increasing the fixed component to the detriment of the variable one, despite the new regulation on executive compensation in force. Therefore, in the extreme case of earning with zero bonus, it does not represent a significant penalty to discipline managers' risk-taking.

The issue of risk-taking has frequently been in the spotlight of banking literature. This is due to the fact that even though banks operate in a regulated setting, bank managers have discretion in making their own decisions that significantly alter the riskiness of these institutions [9,52]. One section in which to use discretion is in the choice of setting up the level and composition of CEO compensation.

CEO remuneration, which operates individually in each bank, has general implications for the risk-taking behavior of CEOs and for banks' performance [53] through the agent relationship between ownership and control [52]. First, CEO compensation and its impact on risk-taking has become a demanding and crucial subject in banking research, e.g., [9], which is of special concern during financial downturns, when moral hazard and information asymmetry questions together with managerial discretion tend to be exacerbated. In addition, at the beginning of the 21st century, banks shifted their traditional target to more volatile investments, such as loan securitization [54]. As compensation policies eventually become more reprobated for inducing too much risk [55], the disinformation to understand bank $\mathrm{CEOs}$ ' risk-taking and their probable false steps to take appropriate and corrective actions to avoid excess risk-taking can induce these bank executives to inattention, such as financing long-term assets with short-term debt. Secondly, we are not wrong to believe that remuneration can minimize type I agency conflict (agent and principal), but the exclusive characteristics of the banking system make it unique with broad worldwide consequences, and if we obviate this, then we are missing a huge portion of the cake.

As critically noted by Zalewska [56], regulation of compensation should address conflicts that originate between principals and the "broad economic and social agents affected by bank operations, policies and performance." So, regulation should guarantee the protection of both parties. This is important because when debating remuneration structures as a gadget to solve a type I agent problem, the banking sector does not fit into the general approach (e.g., equity financed or no social links are involved). There are mainly three drivers for this: (i) environmental issues, (ii) banks' capital structure, and (iii) systemic risk.

It has been a long time (more than 30 years) since the largest European and US commercial banks incorporated environmental issues into their credit risk management. In fact, environmental risks can lead to credit defaults. For example, if a financial institution welcomes real estate collateral as loan security without investigating whether the plant, property, or equipment are involved in contaminating issues, the market will underrate the security value and thus the bank will get a lesser amount (or even nothing) for it when realizing it. According to this, even though most banks have already integrated this environmental risk into their credit risk assessment, they have not done it yet through all the phases of the credit risk management, which can be pernicious due to these risks influencing all phases within the process [57]. Regarding banks' capital structure, it is remarkable that although shareholders (or partners in saving banks) are the real owners by right of banks, depositors and other stakeholders are the "true" bank holders [58]. Finally, the last "systemic risk" driver suggests that individual consideration of banks fails by itself because nowadays they are very closely interconnected, and the failure of one bank can impact the stability of the whole system [59], which magnifies when banks are systemically significant (too big to fail). Furthermore, banks are the essential providers of financing, a role that emphasizes their activity in ensuring and supporting the economic progress of countries. Therefore, related to the second driver, banks' obligations spread far beyond type I agency conflict, but also to type II (stockholders vs. creditors) and type III (stockholders 
vs. other stakeholders). If the banking sector experiences difficulties, the whole society crashes, and in the end, taxpayers are the real superheroes in this pessimistic scenario.

All these peculiarities make the banking industry have its own personality, and thus make banks risk-taking and compensation packages and regulation a particular issue to go through.

\subsubsection{Should Bankers' Pay Be Regulated and How?}

Similar to how alchemists have always looked for the legendary philosopher's stone to convert basic metals to gold, to cure diseases, or simply to grant immortality to living beings, academics, professionals, and society in general have always wondered whether bankers' payments are fair enough, should be regulated, and how they should be structured.

Well, what is clear is that remuneration policies appear to be a weak rather than strong basis to set managers' strategies. There is no sustainable agreement that remuneration packages and their composition definitely contributed to excessive risk-taking before the past financial crisis (but whose effects are still felt). Despite this, even if we consider that they were erroneous, especially those of the non-highest earners according to the European Banking Authority (EBA), "the need for their regulation would not be automatically established" [60]. For instance, banks operate in a regulated environment, so prudential regulators could constrain excessive risk-taking, though it is likely they do not have enough expertise to draft pay structures. In this line, competent authorities should oversee bankers' remuneration from the bank safety and soundness points of view. Ferrarini [60] suggested analyzing the impact of remuneration structures instead of shaping them ex-ante by regulators, which is in fact banks' board duty. Otherwise, boards miss one of their fundamental corporate governance affairs, which hinders to align risk profile to CEOs' incentives. When prudential authorities mandate compulsory pay structures, that partly blocks the legitimate flexibility that compensation arrangements enjoy. Conversely, setting aside the fact that allowing banks to make non-ruled compensation packages is a question that is unthinkable per se, conducting bank activities by prudential organisms would be a plausible solution, with its nuances-for example, more restrictive capital requirements to those financial institutions that adopt more disruptive remuneration tools that accentuate excessive risk-taking. Further insights on this will be seen in next sections of the work.

A second argument that favors bankers' pay regulation is the inherent problems stemming from it. Coming from a long time ago, moral hazard problems are created by "deposit insurance" and "too big to fail" strategies [61]. These policies act as powerful incentives for bank executives to gamble with banks' assets at the expense of government bailouts. Related to bank managers' incentives, another argument consists of the direct or indirect effects on managerial incentives [51]. For instance, asset and capital regulations indirectly affect managers' decision-making; that is, more restrictive regulatory capital levels disincentivize risk-taking by managers and thus being paid in excess. However, altering top-level management compensation results in a direct effect on managerial incentives. For example, influencing bank managers' remuneration effectively reduces returns and risk-taking incentives because risky decisions are no longer rewarded.

\subsubsection{The Role of CSR in Banks}

Even though corporate social responsibility (CSR) exists in both theory and practice [62], there is no unique definition of it. However, the applied explanation of CSR directly connects the concepts of sustainability, non-financial information, and also financial information since it requires informing about the economic situation of firms as well as the social and environmental perspective. Among all the expected definitions, we are able to assert that CSR is the voluntary commitment of companies with the development of society and the preservation of the environment, from its social composition and responsible behavior towards the people and social groups with whom it interacts. CSR is focused on meeting the needs of stakeholders through certain strategies whose results have to be measured, verified, and properly communicated. It goes further than the mere compliance 
with the established legal regulations and than obtaining exclusively economic results in the short term.

The 2008 global financial crisis (GFC) called for an increasing request for CSR activities in the banking industry, and built up society's demand for transparency, corporate accountability, and trust, in addition to responsible financing and investment practices from banks, especially. Banks are internationally known as essential catalysts of (sustainable) economy [63]. Despite the fact that banks must incorporate environmental issues into credit risk assessment, they have apparently more of a small, direct impact on, for instance, the environment and carbon emissions compared to other sectors. However, the indirect effect of banks on sustainable development is clamorous due to their financial capital value chain and their potential significant multiplying effects [64]. The decision of where and how much to invest, fund, or grant insurance to risky projects has substantial implications.

Banking CSR initiatives have plenty of benefits. Firstly, related theories such as the stakeholder theory and legitimacy theory highlight that CSR reporting reduces information asymmetries between bank management and stakeholders, as well as reinforcing the legitimacy of their operations [18]. In fact, more than the $50 \%$ of financial institutions' clients are supportive and interested in banks' CSR activities. Secondly, investors are progressively incorporating environment, social, and governance (ESG) information into their expectations to conduct a more accurate due diligence and evaluation of firms' profitability. For instance, about $70 \%$ of investors integrate CSR information into their investment decisions [19], and $92 \%$ of institutional investors would appreciate corporations to report ESG factors with a material effect on performance [20]. Thirdly, transparent CSR strategies lead to better financial conditions and credit rating enhancement [22]. Fourthly, banks with CSR activities meaningfully outperform banks without CSR implication [65] and improve their compliance and internal reporting systems, reducing internal costs [23]. According to the directive [66], greater transparency triggers better financial and non-financial performance, which translate into long-term consistent growth and trust among stakeholders. Fifthly, CSR activities and reporting are justified as a tool to boost financial performance and corporate reputation [17].

Having said the above, a feasible relationship may be established between CSR strategy and CEO compensation. Although is not directly observable through financial data [67], CEO motivation to engage in CSR activities provides strong information about it. For example, managers will be internally motivated to engage in CSR due to their own interest, being rewarded for doing the right thing instead of having extra compensation; on the contrary, they will be externally incentivized if CSR acts as an instrument within the firm. For instance, if CSR increases shareholders' wealth, it will result in an increase in compensation [68].

Despite all the above motivations, the link between executive compensation and CSR is not conclusive because there are at least two alternative views on this association [25]. First, greater CSR investment improves shareholders' value because better CSR investment involves high-quality employee retention, loyalty, and access to valuable resources. Banks are a nexus contract between shareholders and other stakeholders such as government, regulators, supervisors, creditors, borrowers, and employees, among others. Their claims may be of two types: in explicit contracts (e.g., wage or product warranty contracts) or in implicit contracts (e.g., job security promises and continued service). If CSR is focused on the interest of other stakeholders, they are more likely to support banks' operations, which increases shareholder value and thus the CEO will be rewarded for their effort in improving CSR (value-creation hypothesis). The second view regards "bad" projects. If bank managers over-invest in CSR that is associated with investments in negative net present value projects that transfer wealth from shareholders to other stakeholders, bank managers build their personal reputation to the detriment of shareholder value (value-destruction hypothesis), which penalizes bank managers' compensation.

The conflict of interest is palpable in remuneration structure and CSR disclosing. With respect to total compensation [69], bank managers may engage more in CSR to satisfy other 
stakeholders to reduce agency costs. For instance, if employees notice that bank managers receive larger payments due to their CSR implication, then they will feel unfairly treated, which may cause strikes or less corporate support. Hence, bank managers involved in CSR practices will accept lower compensation, and other stakeholders will be satisfied (internal motivation). Another explanation for the negative relation is that engaging in CSR results in a lower bank risk (less credit risk and litigation risk, labor strikes, etc.), which directly leads to a decrease in total compensation. On the contrary, equity-based compensation (e.g., stocks and options) is expected to be positively associated with CSR involvement. Benefits from CSR practices are likely to occur in a longer time frame and stocks tend to eventually boost long-term performance [70]. CSR may be seen as a long-term goal investment with long-running social benefits (no immediate payout). Another reason is that the CEO becomes a (larger) shareholder. Cash-based compensation (salary and bonuses settled in cash) is a short-term remuneration, so it is expected to be negatively related to CSR. On the one hand, the bonus component is a short-term financial (not social) performance target; on the other hand, salary is the fixed component whose increasing value means that bank managers will be less focused on stakeholders' interest. In addition, salary is the most visible compensation component for employees, so larger differences and wider ranges would provoke workers' disconformity.

Finally, from the regulation perspective, the Global Reporting Initiative (GRI) and the Corporate Register recommend that top-level management remuneration should reflect CSR for the welfare of society, with both positive and negative effects depending on the stakeholder.

\subsubsection{Related Theories}

There are plenty of competing theories that could explain executive compensation as an important corporate governance mechanism and the uninterrupted rebound on CEO pay [42]. However, the debate is served when trying to put them in the same direction. Each theory has its own virtues and discrepancies compared to others, but these contrasting points make it so compensation regulation is continuously changing, improving, and aligning interests among the diverse parties that are involved in the economy. Overall, four postulations are the most sound: (i) the agency theory, (ii) the managerial power theory, (iii) the stakeholders/stewardship theory, and (iv) the hyperbolic discounting theory.

Under the agency theory (as well as the three versions the agency theory is split into: (i) the agency cost of equity, that is, executives who own less than $100 \%$ of the shares not making decisions in the same way as those who have full control; (ii) the agency cost of free cash flow, which denotes agency problems between executives and financial claimants on the disposition of cash flow; and (iii) the agency cost of debt, which reflects the potential rivalry between shareholders and company' debtholders [42,71]), CEO remuneration is basically meant as a relevant corporate governance tool to defeat potential but inherent agency conflicts (even if there are forces that could mitigate or ease the conflicts of interest among groups, they can also originate new problems; see [42]) between agents, mainly shareholders vs. managers. In particular, agency disputes in banks are notable as a consequence of risk management because they form the essential part of their business model. The complexity of banks' day-to-day transactions makes it difficult to monitor risk-taking actions by executives. Thus, their payments are based on performance metrics that act as a partial substitute [72]. In addition, bank positioning implies that other parties are involved. As mentioned earlier, aligning managers' incentives with the interest of stockholders does not mean satisfying all stakeholders, because maximizing shareholders' value does not automatically meet the interest of bondholders. That is, the limited liability of stockholders limits the loss in their investment but not the gains. This attitude fuels the possibility to transfer wealth from creditors to bank executives by preferring risky investments even though they do not produce benefits for the bank [73]. This risk-shifting increases as the bank gets closer to default (less to lose from failure but more to gain from success) because managers, in general, tend to "gamble for resurrection" ("gambling for 
resurrection" denotes the hope of being solvent again by taking risky strategies that are in the executives' own interest but not those of the creditors).

In a wide sense, risk-taking by owners is commonly confronted by the risk-taking by executives. The risk aversion of CEOs is more pronounced compared to owners, who can diversify their risk by holding varied portfolios [74]. Because shareholders are more neutral in this respect, they can induce bank managers to take on more risky investments for potential benefits (e.g., growth, profitability, higher returns, etc.). Shareholders appeal to the more recurrent corporate governance mechanism, compensation via stocks, options, or debt [9].

Bonus payments through non-cash instruments (shares or debt) can be good incentives to take more risk because constant monitoring can be costly or difficult to implement [75]. For the manager-shareholder relation, retribution via stocks transfers a fraction of banks' ownership to executives and could increase long-term performance. For its part, payments via debt instruments are desirable when looking at wider society and shareholders' incentives are not completely aligned with the objective of strengthening the financial stability. In fact, the EBA issued a regulatory technical standard [76] that provides for the payment in convertible debt instruments, which reflects bank's credit quality as a "going concern" (In this case, a "going concern" alludes not only to the idea of being operational and profitable in the future but also meeting regulatory requirements). The underlying purpose is that in debt-based awards, gains are fixed with only downwards adjustments, in contrast to equity awards.

Additionally, under the agency theory, decisions in the area of CSR are likely to uncover high information asymmetry and low planification. Principals and agents rely on pay for short- and long-term performance systems: Managers are more likely to engage in earnings management practices to show larger short-term gains when bonuses are based on annual earnings [77]. If so, executives have a singular financial disincentive to engage in CSR when their pay focuses on short-term incentives. CSR involves taking favorable actions on human rights, safety, environment, diversity, employee relations, and fairness, among others, so it really represents an opportunity cost for CEOs because it has positive long-term benefits and direct negative effects on banks' short-term performance. In this way, CEOs' compensation structure and strategies honestly signal bank corporate orientation [21], so long-terminism provides incentives for CEOs to engage in CSR actions. For instance, long-term pay plans reduce pressure to maximize short-term earnings, and from a competitive viewpoint, CSR reputational effects are more likely to occur in a longer time frame, which hinders potential imitation [78].

The managerial power theory, in contrast, assumes CEO remuneration as an agency problem per se [40]. Although "efficient contracting" navigates in optimal water, that is, the level and composition of compensation matches the competitive market equilibrium for executive expertise, and high earners are high performers to increase firm value because incentives are well aligned, managerial power posits that high-level executive labor can be questioned, which can disregard long-term risks to obtain short-term gains-a rent extraction through compensation structure [40]. This opportunistic behavior rises from the unequal bargaining power between the board of directors and executives, which creates market inefficiencies.

The independence of directors could be a potential solution, but with secondary effects. Independent directors are supposed to protect minority shareholders from expropriation by controlling shareholders and management, and also from latent corporate outrages [79,80]. However, as pointed out by [42], boards formed by outside members can alleviate agency problems between shareholders and managers but can generate agency problems between shareholders and directors. For instance, "independent directors are busy people with higher time opportunity costs" [80] (p. 393), so they can ask for additional rewards, which is at the same time perverse. High remuneration can attract prestigious directors [81] but can also compromise their independence, affecting monitoring effectiveness [82]. 
Lastly, the third inter-related theory is the stakeholders/stewardship camp. Under the stakeholder theory, CEOs will tend to shirk their responsibilities (feeling discouraged) unless they are paid enough with a compensation that aligns, at least, with shareholders [83]. The wider interest groups affected by banks' decision-making extend the framework to promote stakeholder value, and not only shareholder value. That is, an incentive mechanism (compensation) should be conceived to account for the managerial impact on outsiders, which assumes internalizing costs (e.g., demand effects, liquidity concerns, capital requirements, etc.) because benefits are always absorbed.

We would not like to finish this section without postulating a theory that could explain managers' behavior in terms of compensation and preferences. This theory receives the name of the hyperbolic discounting theory, which analyzes human psychology [84]. The point is that a "smaller and sooner" reward is more valuable than a "larger and later" one. In other words, and slightly contradicting the income smoothing hypothesis, managers will prefer timely compensation to deferring a ration. If we move this concept to compensation, present remuneration would gain prominence to the detriment of future profits, which is in line with Kahneman's and Tversky's [41] postulation. They argued that humans are loss averse by nature, so in case of gains and losses being equal, taking losses is more meaningful than the utility stemming from profits. This is essential but critical at the same time due to it involving incentives, and deviation in expected compensation may induce them to incur upward or downward earnings management practices.

\section{European Bank Remuneration Rules}

Undoubtedly, worldwide technological, economic, financial, and regulatory changes modified and in turn reshaped the global economy in a more complex scenario. Practices such as massive and uncontrolled off-balance-sheet financing of loans and the use of sophisticated derivates increased bank profitability by creating risks that at alance were (and are) not easily visible to the rest of the actors, such as borrowers and lenders, or even to the supervisory or regulatory system, which weakened the financial stability purpose of the Basel regulation. In this sense, revisions to the Basel system tackled some of these habits, but that was not the case for the regulation of compensation. It is true that prudential regulation implemented changes such as the measurement of risk-adjusted performance, the scope of new standards, the proportionality principle, etc., due to the increase in pressure from the media, politicians, and the general public, passing from a supervisory to a more regulatory approach. However, though directives were concerned about bankers' remuneration (e.g., provisions on regulatory capital), national implementation exposed shortcomings [6]. All this effectively improved risk management systems and reformed areas of prudential regulation, such as capital adequacy and some banking organizational requirements, instead of intervening directly in bankers' incentives.

As pointed out by the literature on this topic, e.g., [85], the philosophy of shareholder primacy is the main stumbling block to far-reaching reforms. That is, paying executives for just increasing the share price or return on equity (more than return on assets) was a misleading practice that triggered economic disasters. Furthermore, leaving remuneration schemes to bank boards and shareholders encourages excessive risky actions by executives, whereas regulators are unable to even perceive impressive credit fluctuation and the risk associated with it. Even though it occurs, the truth is that historically bad corporate governance mechanisms always result in enormous costs for shareholders, but also for taxpayers, which seems to indicate that "banks managers and owners have limited interests in the consequences of bank failures and systemic risk" [86,87]. Though one may find many bank failures in Europe (e.g., CAM or Bankia in Spain; Commerzbank in Germany; ING in the Netherlands, RBS, Lloyds, and HBOS in Scotland; National Bank of Greece; or, more recently, PNB Banka in Latvia), the assistance to banks is provided privately or even publicly when their bankruptcy may threaten or collapse systemic stability. 


\subsection{Failed Governance and Failed Incentives in the 2008 Financial Crisis?}

It is commonly asserted that the economic impairment in the last financial turmoil was mainly driven by bank management scandals (spread to other industries), together with a lack of transparency and the subsequent government bailouts [64]. These circumstances therefore undermined public trust in the banking industry [88]. As suggested by countless authors, e.g., $[17,89]$, banks must put all their efforts to build their reputation again, triggered by the new and challenging environment coming from the global financial crisis (GFC).

The endless debate about the precise factors that caused the recent GFC will be eternally discussed, with no consensus. An approximation sits in the de Larosière report, in which the members of the high-level group on financial supervision in the EU concluded that, among others, remuneration and incentives schemes within financial institutions were part of the main causes of the GFC. The reason behind it is that it "contributed to excessive risk-taking by rewarding short-term expansion of the volume of (risky) trades rather than the long-term profitability of investments" [90] (p. 10). At this point, it is remarkable to clarify that the GFC was not driven by excessive risk-taking, but rather the erroneous and inappropriate expectation that housing prices would eventually appreciate forever. In fact, bonus plans were sketched assuming a continued appreciation, and not the contrary. However, that does not justify wrong, bad, or weak corporate governance policies.

We may find many changes in the corporate governance reporting, but some are especially crucial for the banking industry. Remuneration policy is the most direct instrument that affects bank governance and bank manager behavior; however, this is not the only one. There are two that are particularly important as well. First, the role of auditors as enforcers is essential [91,92]. Auditors play a significant function in detecting and preventing material frauds and in taking into account a wide range of information in reaching audit judgement; in fact, auditors must evaluate firms' internal control, which is the process designed, implemented, and maintained by those with governance, management, and other personnel to achieve the firms' objectives, reliability, effectiveness, and efficiency of operations, and compliance with applicable laws and regulations. Clearly, evaluating the internal control influences bank managers' incentives. Second, as stated by Gebhardt and Novotny-Farkas [93] and García-Osma et al. [43], is the power and independence (from both politicians and the banking sector) of national prudential supervisors. These two governance characteristics of national prudential supervisors are supposed to influence accounting and bank managers' incentives. For instance, powerful supervisors are predicted to influence the accounting practices (income smoothing) of banks and shape the properties of accounting numbers, and the feature of being independent mitigates such an effect.

Surfing the literature on the compensation matter, one realizes the existence of works discussing the link between financial institution remuneration policy and the GFC (e.g., [4-7]); however, the empirical evidence on this relation is scarce but surprising, e.g., [8,9]. The study of Fahlenbrach and Stulz [8] slightly contradicted the notion that having a better alignment of management interests with those of the shareholders permits taking on less (excessive) risk. In this sense, they showed some evidence that bank CEOs performed worse during the crisis and obtained worse stock returns and worse return on equity. With respect to Ali Shah et al. [9], though with a US sample, they found no clear evidence to support bonus plans having caused the GFC. In fact, the results showed that bonuses reduced banks' risk-taking (total, systematic, and idiosyncratic risks) in the pre-crisis period, and that more confining shares and options granted to CEOs spanning 2009 and 2013 also decreased banks' risk-taking. Apparently, long-time-to-maturity options reduce excessive risk, but whether CEOs will decline risky (high-return) projects remains inconclusive.

Despite the limited empirical references, the incentives in such remuneration practices have played a serious role in making financial decisions. The existence of powerful incentives to increase leverage and risk makes banking regulation even more decisive 
than in other sectors. For instance, in order to better align executives' interest with that of shareholders (to maximize returns to shareholders), executives have usually been rewarded with stock options and bonuses linked to return on equity. These forms of compensation encourage "seek bigger and riskier bets" behaviors [85]. As shown by Haldane [94], increasing leverage may hike return on equity, which necessarily is accompanied by an increase in risk. To do that, bank employees are encouraged by their superiors to make risky loans or offer other convoluted financial products so as to meet revenues targets, without taking care of borrowers' repayment as a consequence of "high-powered incentives" via remuneration. Probably, CEOs and the rest of the top managers had the right incentives (short- and long-term incentives), but maybe the problems came from deficient risk management systems at some large banks whose decisions and their aftermath affect the whole economic system. For example, top managers did not know or understand what their dependent staff were doing. Now, did bank governance contribute to the financial crisis? Is remuneration policy partly responsible for bad bank governance?

No doubt, the financial crisis triggered the restatement of the global corporate governance principles of financial institutions "in the belief that governance failures contributed to these institutions' failures in the crisis" [1] (p. 10). One the one hand, the bank governance perspective has substantially changed over time. Even though the "principles of corporate governance for banks" were originally published by the BCBS (by the OECD in general) in 1999 to assist supervisors, many legal systems shifted after the crisis from a supervisory to a regulatory approach. Taking a collaborative part in bank management is not enough, but the 2015 edition of the BCBS guidelines also calls for an "effective implementation of sound corporate governance" that requires "legal, regulatory and institutional foundations." On the other hand, compensation plans are more in the spotlight than corporate governance issues per se. Remuneration is more politically charged so voters are more involved and then interested in downturns.

According to the above, the financial crisis has definitely put under serious scrutiny both remuneration policy and incentive design in the banking industry [3], although some empirical studies found no evidence that deficiencies in corporate governance arrangements were a fundamental originator of the financial crisis, e.g., [10]. Nevertheless, investors, supervisors, regulators, and even politicians have been discussing the level and structures of compensation plans that appeared to exacerbate risk-taking and inspire short-termism. Even though "the success of the EU regulation of bank compensation practices is contingent on the global adoption of such rules" [6,87], these guidelines seek to align risk, performance, and remuneration in order to reduce excessive risk-taking by the banking industry.

In addition to compensation rules, CSR practices (sustainability disclosure) may help in restoring banks' reputation and avoiding an inappropriate lack of transparency in remuneration plans. For instance, CSR reporting facilitates transparency but may be detrimental to maximizing bank CEO remuneration because it tends to reduce firms' risk profiles $[45,95]$. For that reason, among others, the most widespread and used CSR reporting framework-the Global Reporting Initiative (GRI) Standards-encourage banks to report this non-financial information with the Financial Services Sector Supplement (FSSS) that particularly addresses and guides financial institutions [96,97].

\subsection{Recent Regulatory Development in Europe}

The Financial Stability Board (FSB) was formed in April 2009 as an international body that monitors and deliver recommendations about the global financial system. It was established by the 20 leading economies (G20) and was mainly composed of politicians (governments) and bank supervisors (central bank governors) to guarantee financial stability. Despite its short run, the FSB immediately issued the Principles for Sound Compensation Practices, which the Committee of European Banking Supervisors (CEBS) subsequently used to propose the CEBS Guidelines on Remuneration Policies and Practices in 2010. Therefore, this legislation contained compensation proposals based on prudential oversight 
and included that member states should ensure that financial firms have remuneration policies that promote "sound and effective risk management" and do not feed risk appetite.

The timeline of remuneration rules has not been a quiet path but rather a continuous give-and-take among European member states. The FSB's proposals were drafted under an international perspective and framework that left room for country-specific regulation. In this sense, the UK and USA had ultimately opposing opinions in such practices, so they decided to accept them partially. In January 2010, in the European context, the Financial Services Authority (FSA) implemented the FSB principles but with remuneration rules for UK-based banks, published initially on 12 August 2009. Later, in January 2011, remuneration requirements were incorporated into the Capital Requirement Directive III (CDR III), applicable to all EU jurisdictions. An example of this is that more than $50 \%$ of variable remuneration awards are required to be delivered in non-cash instruments (shares, debt), which creates incentives aligned with long-term value creation and the time horizon of risk.

To sum up the next steps, the EBA took over the ongoing functions and responsibilities of CEBS from 1 January 2011 [11]. The "Guidelines on sound remuneration policies" was issued by the EBA under the 2013/36/EU Directive (CRD IV) [12] and Regulation (EU) No. 575/2013 [13] (hereafter Guidelines). These Guidelines were applicable as of 1 January 2017 and addressed to ensure fair play, taking into consideration not only the nature, scale, and complexity of banking activities but also covering all employees.

\subsection{Banks' Remuneration before and after the 2008 Financial Crisis}

The financial crisis supposed a serious turning point to change what was being done until then. Before the crisis, no bonus cap stood; there was no restriction on cash vs. non-cash instruments in variable remuneration; deferral, malus, and clawback (according to the Guidelines, retention is an instrument to align identified staff (i.e., staff whose professional activities have a material impact on the institution's risk profile) compensation with the long-term interest of the bank. Retention is an ex-post risk adjustment mechanism that consists of lowering awarded cash remuneration or reducing the number or value of awarded instruments in response to an adverse bank development via value or risk. It may take the form of malus or clawback. Malus is a soft clawback and applies to the deferred but non-vested bonus, whereas clawback occurs when variable remuneration has already been paid or vested) arrangements were not regulatory requirements; and performance measures were not risk weighted. In the post-crisis things have changed in a more constrictive sense. A bonus cap of $100 \%$ was installed, although the ratio variable to fixed can increase to $200 \%$ with shareholders' approval. The premise behind this scheme is that the expectation of large variable compensation awards intrinsically creates adverse risk incentives that cannot be merely alleviated by ex-ante and ex-post risk adjustments. Therefore, a ceiling on variable pay should hinder excessive risk-taking, as the upside benefits are limited. The palpable consequence is a shift to higher levels of fixed remuneration to offset the variable reduction. (a shift to higher levels of fixed remuneration is not always possible. The compensation must be considered fixed when it is non-discretionary, non-varying, predetermined, and thus non-revocable, and independent of performance. If there is any doubt about the nature of the fixed payment, then it is automatically classified as a variable component (Guidelines, paragraph 116).)

The main compensation adjustments are especially linked to the variable component. For instance, $50 \%$ of this must be paid in cash and the other half via non-cash instruments. Additionally, $40 \%$ of all variable remuneration should be paid upfront, with $60 \%$ deferred. In this respect, all deferred remuneration that has not yet vested may be subjected to malus. Figure 2 graphically shows the longer deferral rules in comparison to old ones that went into force at the start of 2016. It reflects the desirable claims of the Financial Regulatory Authority (FRA), the FCA, and the PCBS. The rationale is that longer deferral periods better align the risk horizons of key individuals with the long-term safety and soundness of the firms for which they work. However, the Financial Policy Committee (FPC) expressed 
discontent in their November 2012 financial stability report that they appeared insufficient because deferrals should also seek to align awards to the usual business cycles that banks operate in and underpin financial industry performance. They concluded that long-term incentive plans (LTIP) were much shorter ( 3 to 7 years) than the estimated length of the credit cycle (8 to 30 years), though more in line with the average business cycle (5.5 years).

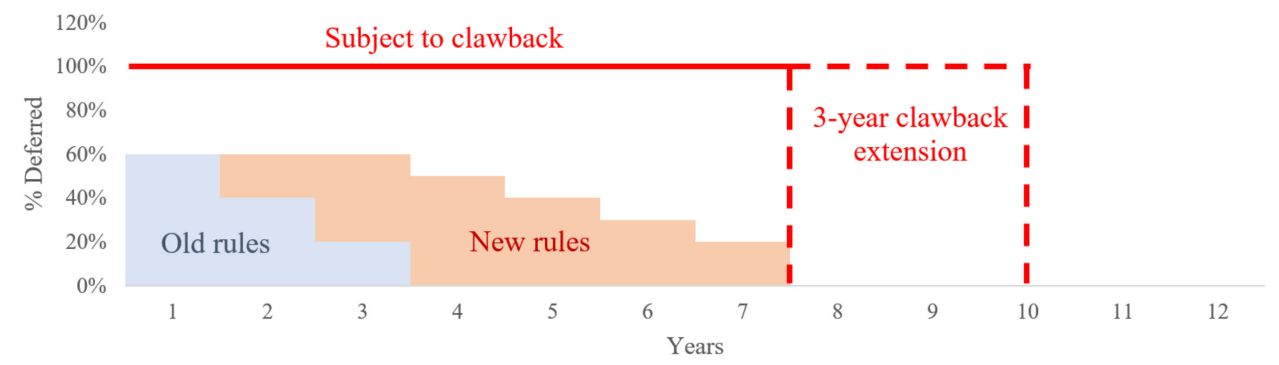

Figure 2. New extended deferral requirements. Source: own elaboration based on the FSB Principles for Sound Compensation Practices.

The Guidelines also mention that clawback arrangements are now part of regulatory requirements since they act as a provision, taking back vested variable remuneration as a result of misconduct or risk management failings. Performance metrics (to go deeper in the relation between performance metrics and CEO remuneration, see Doucouliagos et al. [98], Murphy [42], Dutta and Fan [99], or Tahir et al. [100]) are ex-ante adjusted for risk-taking and may be split into four: (i) risk-adjusted returns metrics (e.g., economic profit or return on risk-weighted assets), (ii) prudential metrics (e.g., healthy balance sheet or capital levels as a share of risk-weighted assets), (iii) strategic metrics (e.g., market growth, cost savings, or investment in human resources), and (iv) conduct metrics (e.g., customer outcomes or compliance with regulation). The fundamental idea is to account for operation, credit, and liquidity risks in financial institutions and contribute to the safety, soundness, and stability of the financial system. Therefore, forward-looking performance measures make it possible, or at least facilitate, decision-making in loan-loss provisioning to operate with an aggressive or conservative credit policy.

Finally, the proportionality principle is part of the Guidelines' backbone, which is also encoded in CRD IV. This principle matches the risk profile, risk appetite, and strategy of any financial institution but considers dissimilarities as well in their characteristics (size, geographical location, structure, business model, and cycle). Therefore, this flexibility tamed the claimers who advocated for the no application of compensation policies because it requires more refined remuneration plans for larger and "crypted" banks without dragging smaller ones to do the same but in a proportional manner. However, an exception to the proportionality axiom is the bonus cap, which applies to all corporate governance and risk management areas in all banks.

Say-on-Pay Issue

In line with the above, the remuneration policy therefore involves two board committees: a risk committee and remuneration committee. The former controls the risk appetite and the later cooperates with the supervisory figure in designing the remuneration policy. Even though the latter is compulsory for significant financial entities but desirable in the rest, the EBA recommends that the annual general meeting (AGM) approve such a compensation protocol. In this sense, the only way to agree on a variable to fixed ratio of $200 \%$ is by AGM approval, and at this stage the "say-on-pay" (SOP) issue comes out.

The "say-on-pay" concept refers to the right of shareholders (AGM) to vote on whether they are for or against the remuneration of identified staff. This became popular and was empowered by international organisms as a consequence of the perceived boost in executives' rewards [72]. However, the debate is served because of the contrasting points of view [47,101-103]. Defenders argue that it strengthens board of directors (BoD) and share- 
holder relationship, whereas critics believe that it is reactionary and counterproductive rather than proactive, claiming that it diminishes the authority or supremacy of the BoD. When analyzing the data on this matter, one may realize its importance and make their own conclusions. To do so, we collected the SOP data from the 301 financial firms listed in S\&P 500, the most representative world market growth index, spanning from 2011 to 2019.

Figure 3 matches the average SOP\% in favor of the remuneration policy and the revenues achieved over time. Even though the observed relation does not imply causality, the numbers seem to contradict the evidence of Fisch et al. [103]. They found that when firms perform well, shareholders do not care about excess payment; however, the historical SOP data slightly denote less consensus (decreasing SOP\%) among shareholders when revenues increase. Although the empirical findings in the literature may notice caution about the potential value of the SOP vote, the global financial institutions appear to evidence that executive remuneration plans may still be short-term structured in spite of the new Guidelines and perhaps top managers are still overpaid according to their risk exposure and interest with the bank. Furthermore, revenue distribution is relevant, alluding to the notion of "one size does not fit all." As can be observed in Figure 4, shareholders are more prone to being in favor of remuneration policy when revenues are lower and inverse. However, this last behavior changes when revenues range between 0.5 and 0.95 percentiles (USD $162 \mathrm{MM}$ and USD $4443 \mathrm{MM}$ ). This representative $45 \%$ of the sample with more shareholder approval evidences that issuers' and owners' approaches to the vote on executive compensation are still in a developing process [103].

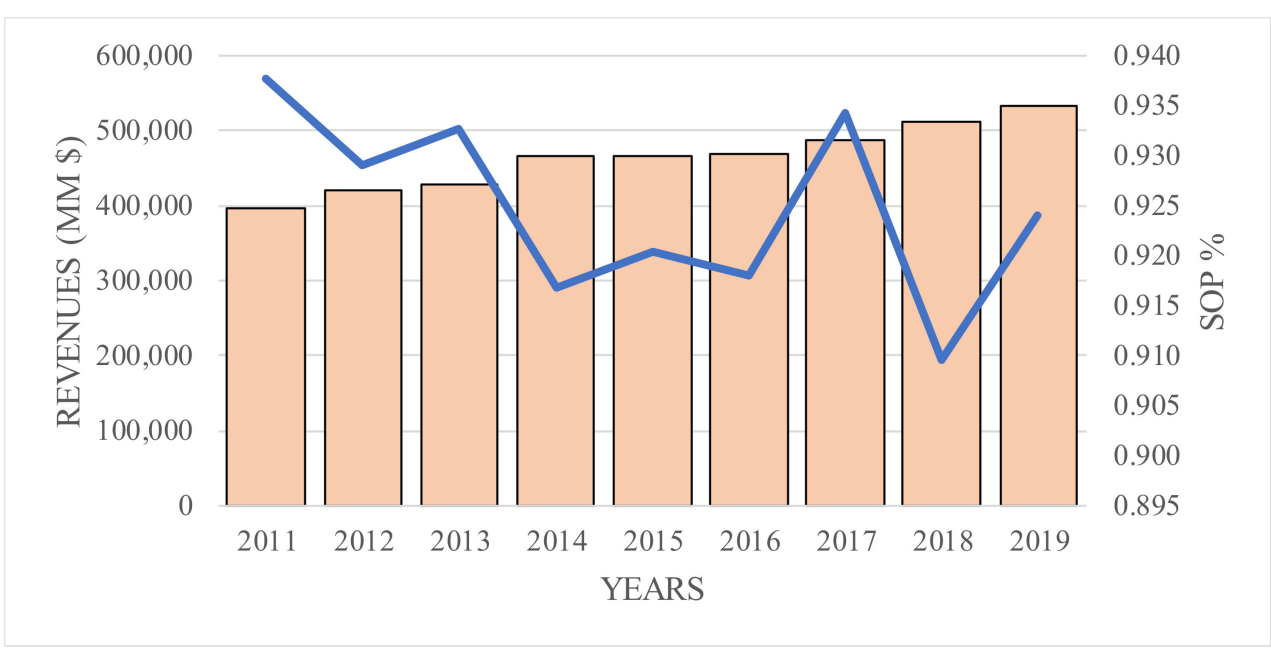

Figure 3. Revenues and say-on-pay percentage over time. Source: own elaboration from the banking sector data provided by Farient Advisors LLC website.

\subsection{The Interest of the Government in Banks' Remuneration Practices}

Many empirical studies have taken into consideration for their analysis the effect of size because the scrutiny level depends in most of cases on how large the bank is; in particular, some of them have made quartiles or percentiles partitions [103,104]. Bank size and strategies mostly respond to national culture. This is a key point because executive compensation has evolved over time and thus is responsive to economic and political fluctuations. In fact, all competing theories and broad approaches must be determined by firms' institutional environment [42]. For example, Almadi and Lazic [105] demonstrated how institutional factors influence CEO incentive-based compensation and then earnings management practices. More specifically, Anglo-Saxon countries such as the UK and Australia count more on earnings smoothing for earnings management than others, and their CEOs are paid on average $14.5 \%$ higher than their next highest paid executives, whereas the percentage of other countries such as Germany and Austria is reduced to 
10.7\%. Moreover, Anglo-American countries have higher levels of investor protection, stricter legal enforcement, and better governance systems.

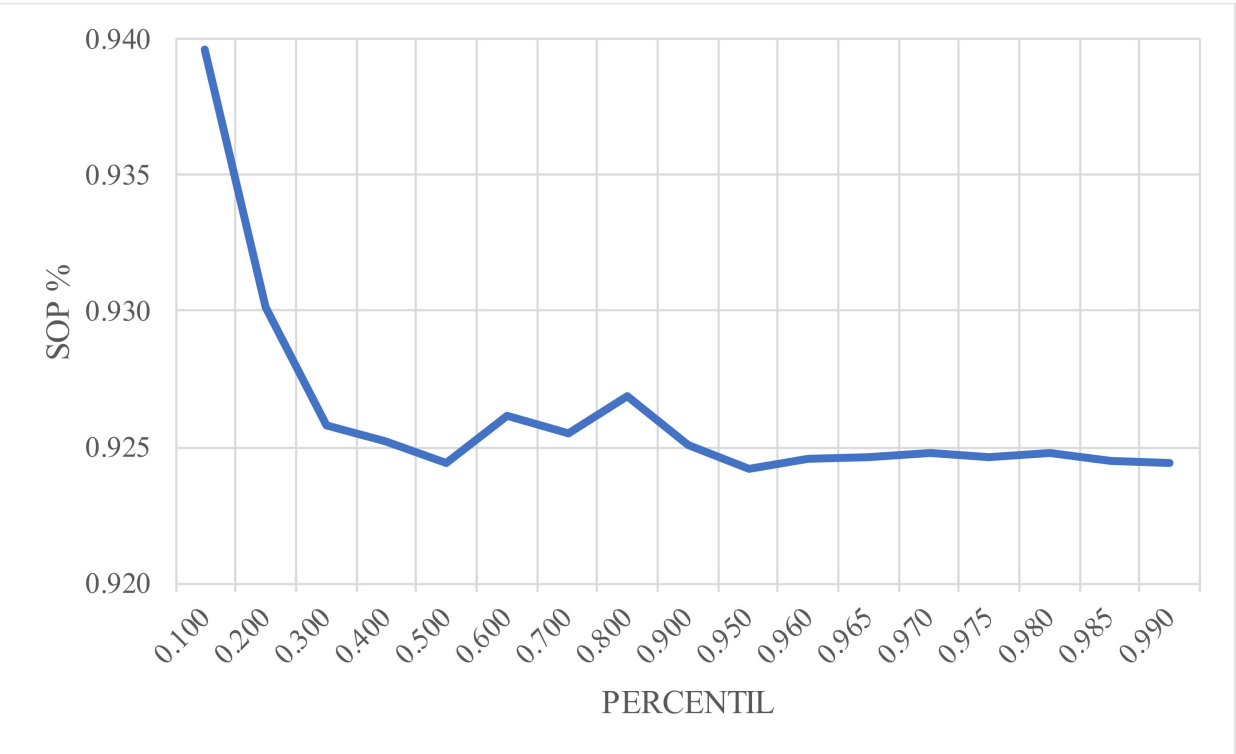

Figure 4. Say-on-pay scheme by revenue percentiles. Source: own elaboration from the banking sector data provided by Farient Advisors LLC website.

Despite explaining executive remuneration becoming tough and convoluted, we must not forget that government intervention has been one of the meaningful drivers of such corporate governance policies [42]. Indeed, the FSB is composed of politicians and bank supervisors, so they probably account for the financial stability but also for their supremacy when shaping compensation legislation, so any argument discounting political factors is riskily sketchy. For that reason, the Guidelines require effective supervisory oversight, firstly at the micro level (risk and remuneration committees) and secondly at the macro level (supervisory bodies). Related to the latter, the supra supervisory organisms must guarantee the implementation of sound compensation policies and practices. In case of failure, they would first take prompt and persuasive remedial actions and if necessary, appropriate corrective actions to offset any potential systemic disgrace, such as increasing capital requirements or pressuring banks on loan loss provisioning.

Coming from the 2008 financial crisis, central banks and governments implemented state aid procedures to safeguard financial stability and banking industry activity. That implied rescuing ailing banks from bankruptcy and preventing potential systemic collapses. Clearly, if upgrading wide corporate governance does not work, then bank regulation and supervisors have to interfere in bank governance, which also covers compensation policy, trying to balance equity, debt, and risk governance [87]. In terms of lobbying, regulators and supervisors eventually became a very involved and powerful stakeholder in banks. The excessive risk-taking by banks may generate large social costs (negative externality) and shocks to the whole economic system [48], and that is one explanation of why banks strongly drag the attention of politicians and governments agree to protect them, even though this state intervention, which is also communicated and examined by the Commission, may take the form of public ownership or financial support [106] and not always solve the problem. As noted by Calomiris and Jaremski [86] and de Andrés et al. [87], the comprehensive Guidelines try to convince the EBA and the single supervisory mechanism (SSM), but the social importance of banks may weaken the supervisory effectiveness in confining systemic risk because, among others, a stakeholder approach would be preferable to a shareholder approach. Calomiris and Haber [107] showed that regulatory failures often trigger prudential reforms. Barth et al. [108] found that market discipline may act as a systemic risk stabilizer, opposite to prudential requirements. Brown and Dinc [109] 
evidenced the potential of election years, which somehow slows down the closure of insolvent banks due to the regulatory recognition of major bank losses. Maybe all these results need to be fixed by the desirable and dreamed governance characteristic of being independent from the political and industrial perspectives [43].

\subsection{Are the UK and EU Destined to Be Rivals?}

Going back to stabilization aids, regardless of its form, national and international support is not costless. In return, in the European context, the compliance of several conditions is "compulsory": stringent dividend policy, higher solvency ratio, and limits to executive remuneration. However, there are notable differences in the application of the Guidelines on sound remuneration policies in Europe, concretely between UK and the rest of the EU. It is noticeable that the first major financial regulator to respond to the financial crunch with the establishment of a remuneration code was the UK Financial Services Authority (FSA), which was the forebear of the Financial Conduct Authority (FCA) of April 2013. This code has been progressively amended to meet CDR III and IV requirements. The final Remuneration Code eventually formed part of both FSA and the Prudential Regulation Authority (PRA) Handbooks. Notwithstanding both, UK organisms share responsibility for assessing compliance with the Remuneration Code. The FCA takes it from a conduct point of view whereas the PRA considers it from a prudential perspective.

All UK firms must comply with all existing national requirements on remuneration policy and practices and also with all EBA Guidelines aspects, but with several specific clarifications. For instance, the main relevant exceptions we may point to are the PRA notification to the EBA in noncompliance with the bonus cap (100\% in general and 200\% with shareholders' approval) and that the PRA and FCA will retain their current approach of requiring the proportionality level-three financial institutions to disapply the pay-out process rules and bonus cap. Even though this kind of exigence does not go beyond a simple demand so far, it becomes transcendental since it brings to light two existing and potential threats: (i) excessive compensation in some countries in the European area, and (ii) rapid migration of bank executives to other countries with "laxer" remuneration policies.

It is generally and justly believed that international financial standards, more specifically governance and remuneration rules, are usually formulated so that countries may have certain flexibility to implement them and thus smooth or dilute conflicts of interest within the individual regions [1]. This is because as the institutional theory indicates, the context powerfully influences governance and executive pay [34]. In line with this, overall problems on executive pay matters fundamentally arise when comparing Anglo-Saxon and non-Anglo-Saxon countries. The two threats mentioned above mainly relate to this endless comparison and it clearly manifests in the reality, where the new European map drafted by Brexit denotes a direct punishment for EU banks, with the exception of UK financial institutions (in this scenario, UK banks would not be under EU compensation requirements), and at the same time it gives UK banks a room to receive the best executives, whose predilection for higher variable remuneration is notable but reasonable, making divergence in the EU more accentuated, if possible.

To see that, we collected the data from EBA reports on top European countries [26-33], which span from 2010 to the of end 2017. Doing so allowed us to observe EU banking remuneration trends over time regarding higher earners (HEs) (those who earn more than EUR 1 million a year). Furthermore, it also allowed us to distinguish those considered the main material risk-takers (identified staff or MRTs by the academia, though the concept is not clear enough [56]) from those who are not (non-identified staff).

Figures 5 and 6 show the proportion and number of HEs and identified staff, respectively, by region, that is, in Europe and the UK separately. We observed a significant increase in HEs over time, especially from 2013 to 2015, with a growth of $61.8 \%$ (5142 HEs), and a steeper slope referring to identified staff of 135\% (4408 HEid). This trend held from 2015 to date. Another important issue to point out is the fact that the vast majority of HEs and identified staff (close to $80 \%$ ) arose from the UK rather than the rest of the EU. 
According to these basic and preliminary results, it is remarkable that the EU eventually became concerned with remuneration policies and made relevant advances towards the identification of MRTs; however, EU standard setters may have partially ignored the UK environment, at a time when it was probably leaving the European Union.

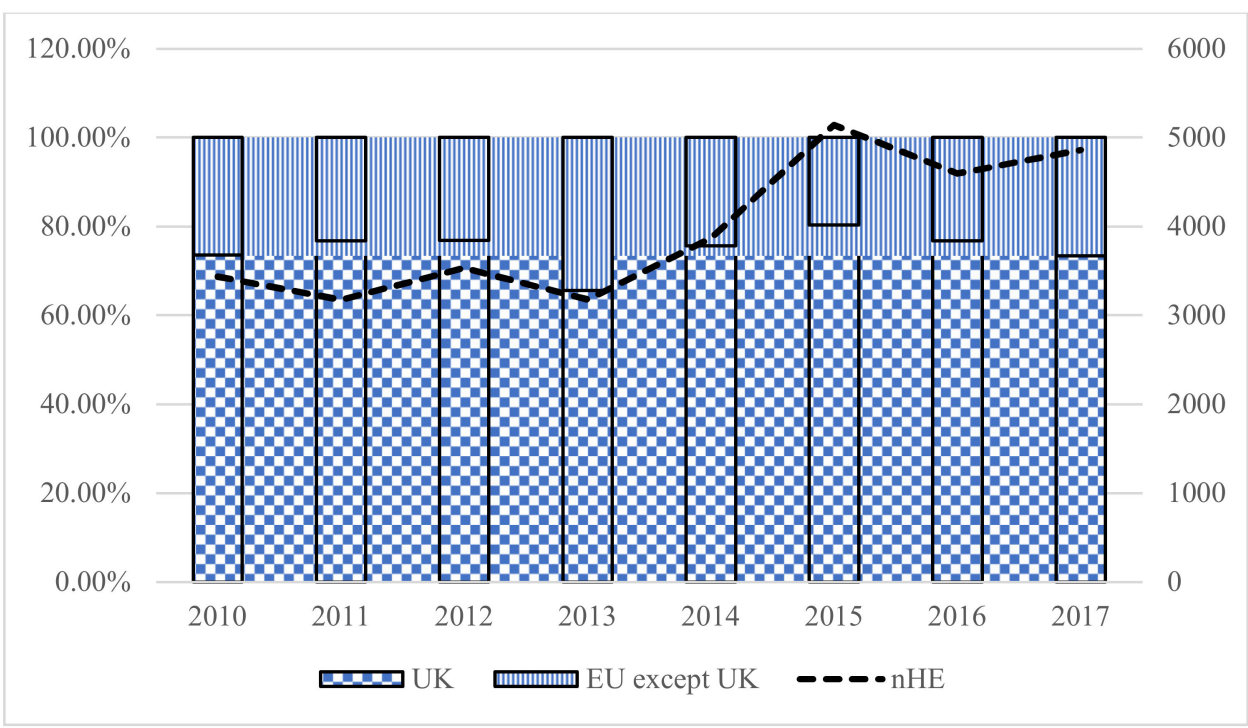

Figure 5. Proportion and number of higher earners by region. Source: own elaboration from the data of EBA reports.

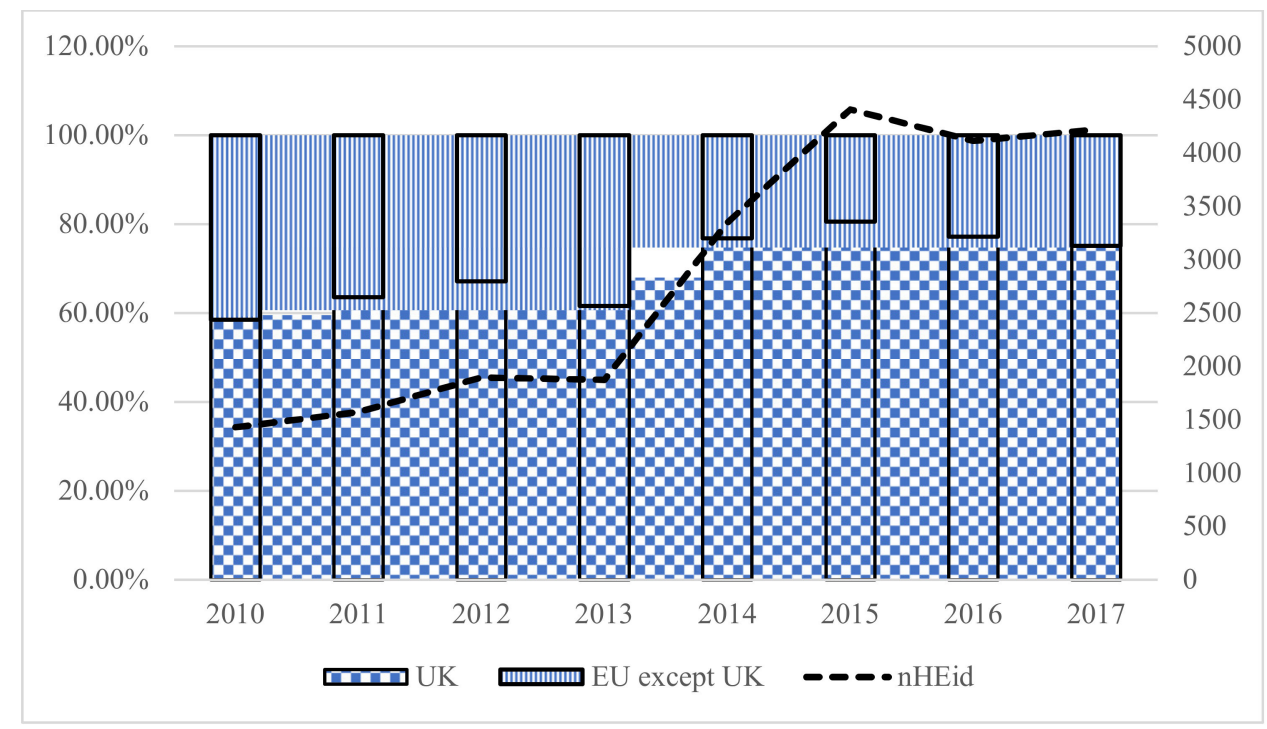

Figure 6. Proportion and number of identified staff by region. Source: own elaboration from the data of EBA reports.

As the central debate and controversy lies on the variable-to-fixed remuneration ratio (bonus cap), we next plotted several significative and intuitive charts that explain the compensation reality. Following the remuneration rules, Figure 7 presents an indicative reduction in the bonus cap (from $200 \%$ to close to $50 \%$ on average) for professionals who had a material impact on banks' risk profile, alluding to a previous excessive pay, whereas this ratio held for non-identified staff. We also noticed an increase of 2.5 times the percentage of identified staff compared to before 2013. This tendency could be explained for the 2013 PCBS recommendation for larger deferral periods, which in theory better aligns the risk prospect of key individuals with the long-term safety and soundness of banks, even though they should be estimated considering both business and credit cycles. From a 
wider HE perspective, the variable-to-fixed remuneration ratio experienced a significative decline of $168 \%$ (from $268 \%$ in 2011 to $100 \%$ in 2017), as seen in Figure 8. In addition, the compensation legislation was accomplished in terms of deferrals (about $60 \%$ of the variable part was deferred, then $40 \%$ was vested immediately).

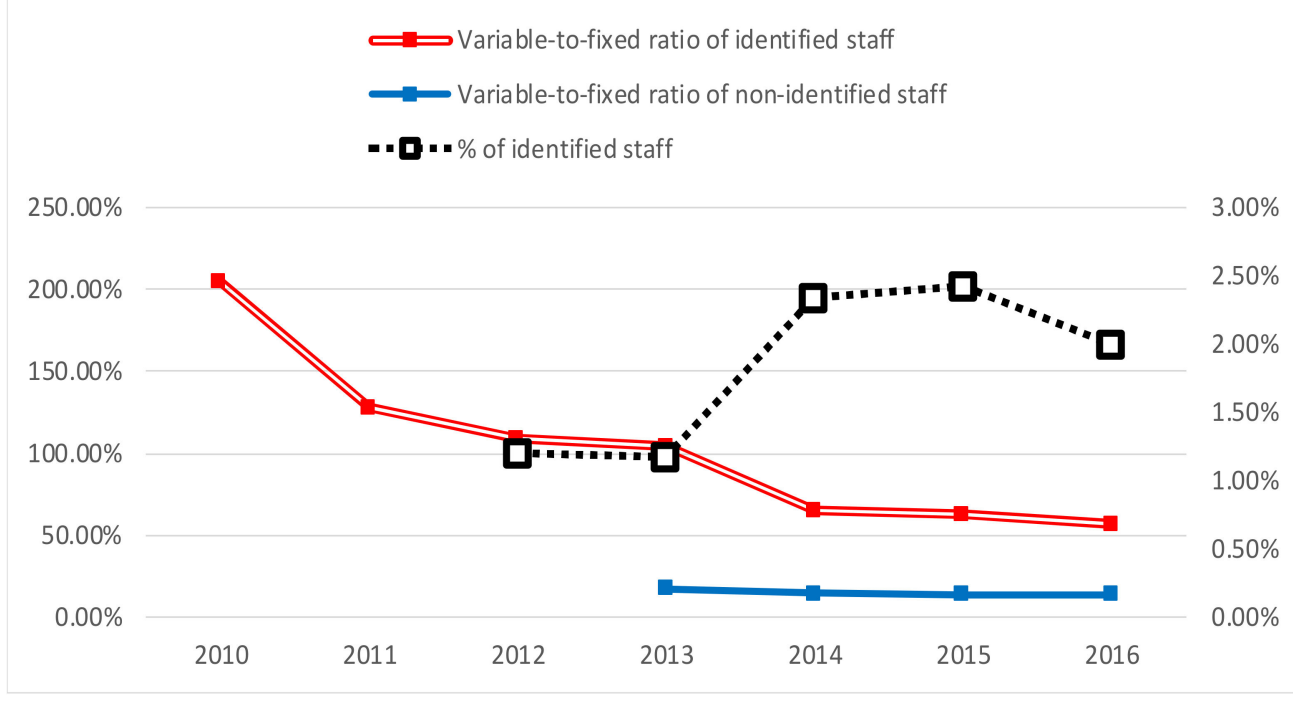

Figure 7. Proportion of identified staff and variable-to-fixed ratio of identified and non-identified staff. Source: own elaboration from the data of EBA reports.

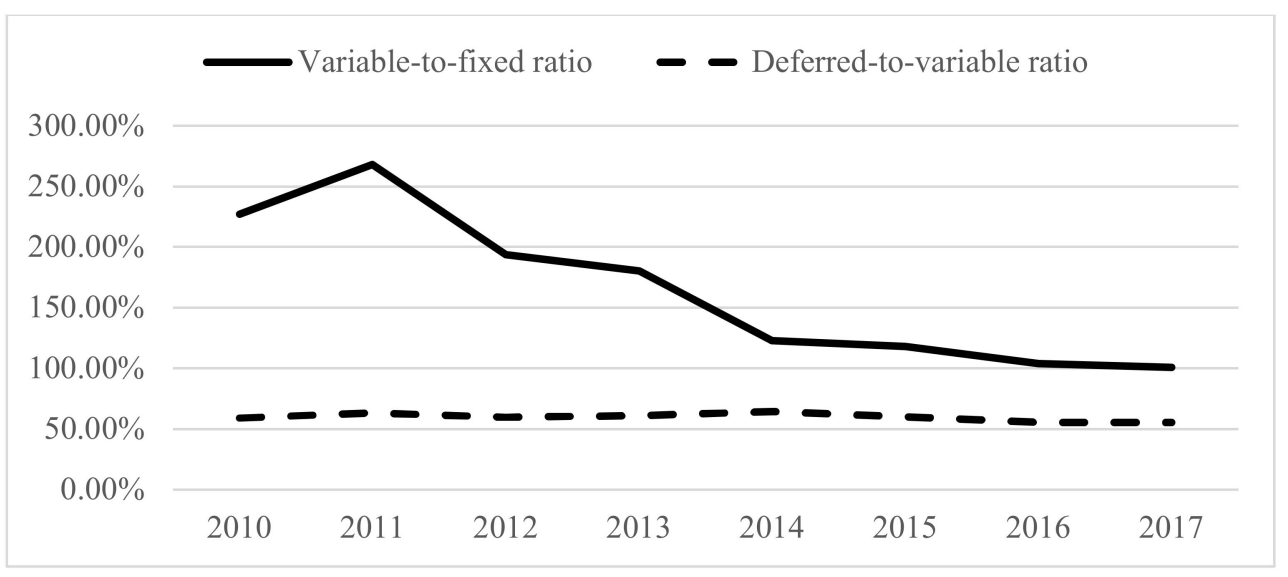

Figure 8. Proportion of variable-to-fixed and deferred remuneration ratios. Source: own elaboration from the data of EBA reports.

The popular term opened to extensive discussion has undoubtedly been the bonus cap. Even though the EBA Guidelines connect remuneration with performance, risk profile, and the business cycle more than ever before, the EBA seems to be conscious that its Guidelines may motivate fixed pay practices to mutate. Managers and top executives will look for other alternatives to offset the limits for variable-to-fixed ratios, especially in banks. Figure 9 demonstrates that even after the beginning of the financial crunch, the HEs from the UK were still the most paid in EU, and the rest of the EU countries did not almost exceed the 200\% limit. However, the bonus cap forced them to reduce it and thus to converge with the rest of the EU parties. As can be seen, the limit of $200 \%$ was accomplished after 2014, when the CRD IV provisions came into force, including the bonus cap and criteria for MRTs. Undeniably, the variable-to-fixed ratio consists of two numbers: The numerator is the variable component, whereas the fixed remuneration occupies the denominator. If restrictions on the bonus cap constrains executive pay, then the solution 
is either lowering the bonus pay and keeping the fixed remuneration, or maintaining the variable pay in exchange for increasing the fixed part or a mixed of them, and that is indeed what happened when remuneration rules were implemented. However, this behavior may have been induced by political pressure [5] or maybe as a consequence of having higher reference points for their remuneration [110] - for instance, if the reference mark was before the Guidelines application, afterwards executives would prefer at least the same as before, so when the bonus cap was applied, the only alternative to boost pay would be to expand the fixed component.

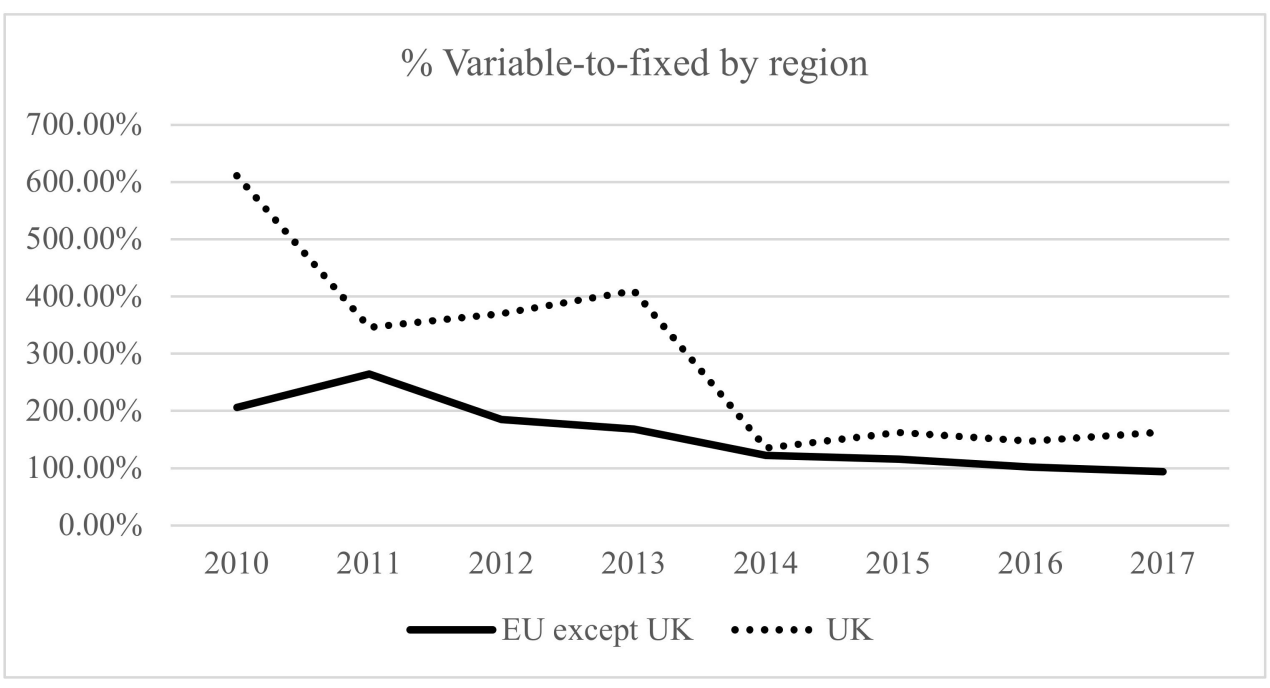

Figure 9. Proportion of variable-to-fixed ratio by region. Source: own elaboration from the data of EBA reports.

Analyzing the information disclosed in the EBA reports about the remuneration of HEs, we noticed it in order to comply with the bonus cap. Figures 10-13 graphically represent the evolution of the average variables and fixed components spanning from 2010 to 2017. In Figure 10 we observed how the variable pay diminished from 2010 to 2017 and the fixed pay literally tripled its value. However, looking at the total remuneration is a bit foggy; therefore, the data tendency by HEs was refined. Once again, the plot seemed to be a funnel in which variable and fix pays converged in 2014 (Figure 11). However, was this equal across countries? Well, on average, the amounts significantly differed between the UK and the rest of the EU countries, again.

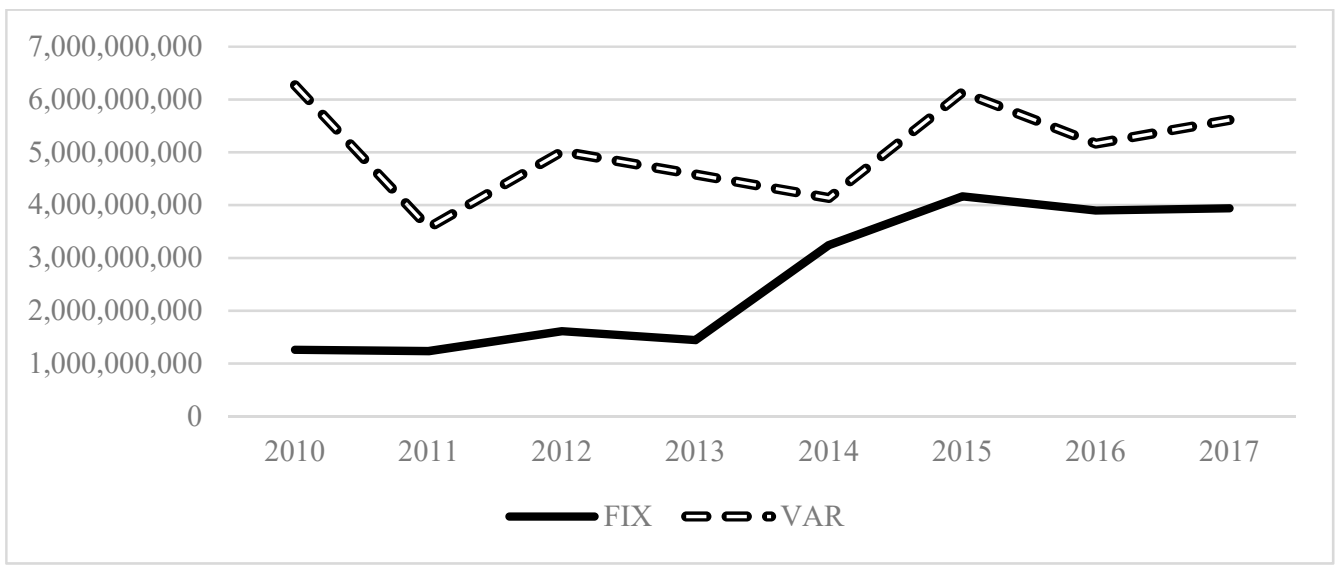

Figure 10. Total fixed and variable remuneration. Source: own elaboration from the data of EBA reports. 


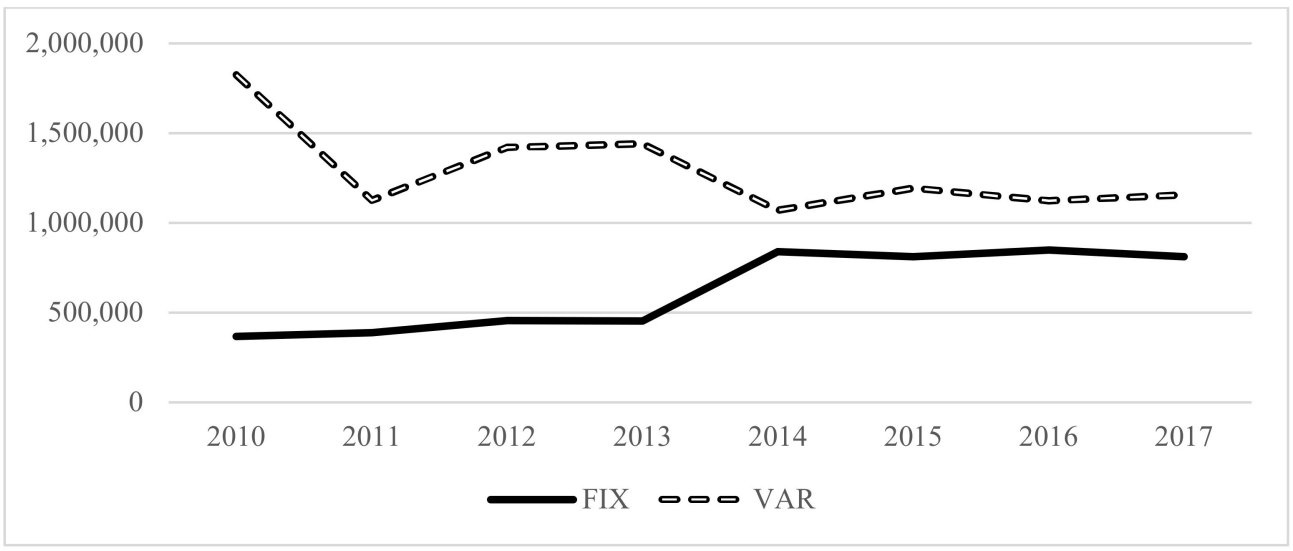

Figure 11. Total fixed and variable remuneration per HE. Source: own elaboration from the data of EBA reports.

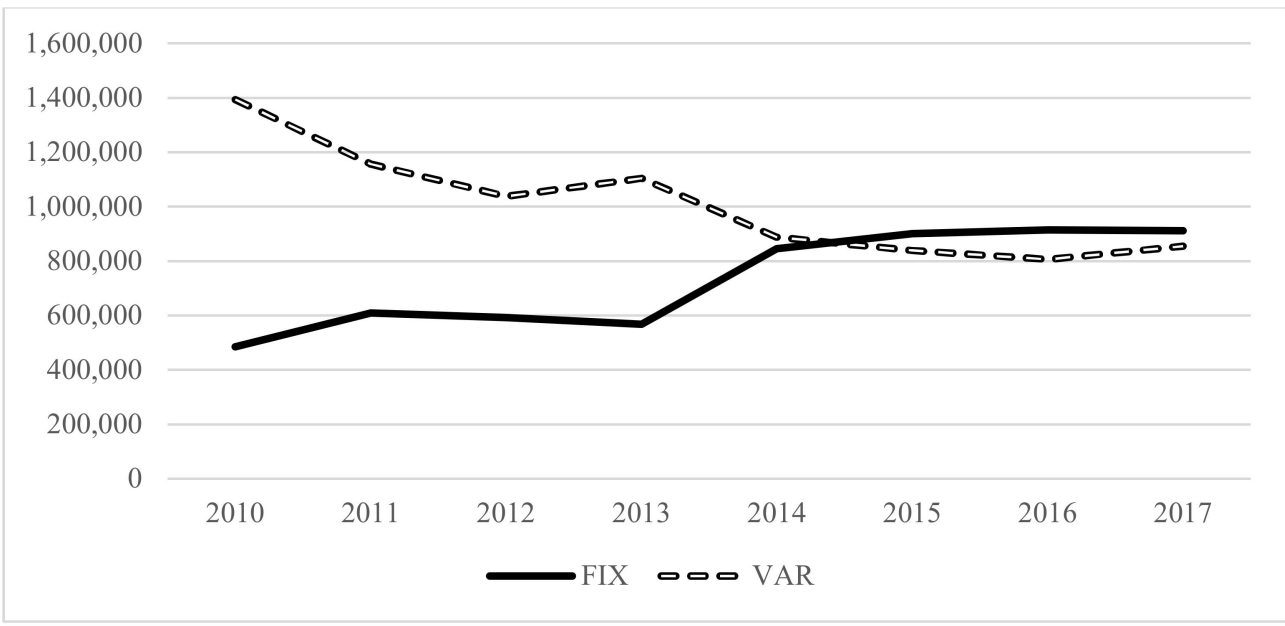

Figure 12. Total fixed and variable remuneration per HE in the EU, excluding the UK. Source: own elaboration from the data of EBA reports.

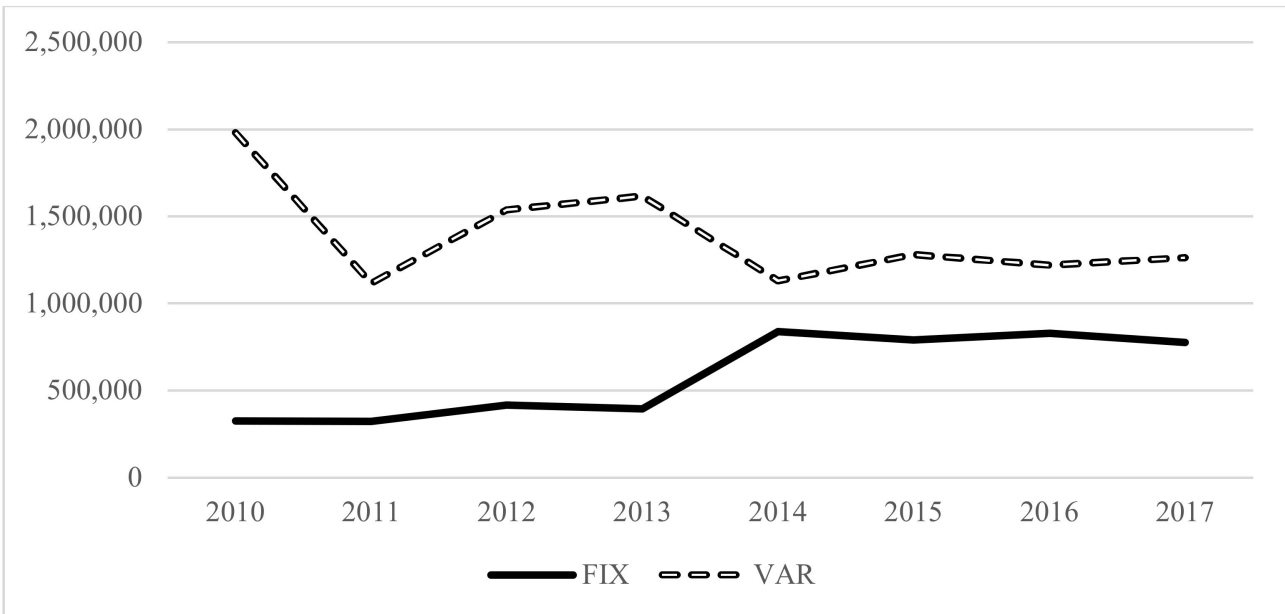

Figure 13. Total fixed and variable remuneration per HE in the UK. Source: own elaboration from the data of EBA reports.

Figures 12 and 13 show the total fixed and variable components of remuneration plans per HE in the EU (except the UK) and in the UK, respectively. The results are more than 
evidence; in the EU, we noticed a clear increase in fixed pay to the detriment of the variable pay. What is representative here is that at the time the bonus cap became applicable, the amount of the fixed component exceeded the bonus pay in absolute terms. This is impressive but perfectly coherent since a cap in variable pay will necessarily lead to an increase in the fixed part [5], as said before. Moreover, unreported results indicate that more than the $50 \%$ of the fixed remuneration was paid via instruments instead of cash. Therefore, being speculative, this behavior could be a signal of the attempt of European banks to circumvent or partially avoid the new Guidelines. At the same time, UK bankers also denoted a herding behavior. As also observed before in Figure 9, Figure 13 demonstrates that UK bank HEs were more variable paid, and that the reduction in this component does not imply (because maybe they did not need it) an increase in the fixed pay that overpassed the variable one. Thus, British bankers appeared to continue keeping the variable remuneration up, suggesting their preference to remain in the UK in case of a Brexit scenario.

\section{Earnings Management (Income Smoothing) and the New Remuneration Rules}

Earnings is a proxy for accounting quality [35]. As earnings quality is not directly observable and its various definitions may be confusing, among the existing proxies, earnings management is the most used in the empirical literature. Earnings management generally refers to the discretionary (and opportunistic) use of financial information. For instance, it consists of a situation in which managers use their judgment in shaping financial statements [111], either to mislead other contractual parts, creating information asymmetries about the underlying financial performance of the firm, or to influence accounting numbers so as to maximize top-level managers' remuneration [77,112], among others. Income smoothing is another proxy for earnings quality but is strongly related to earnings management. Income smoothing is the practice of moderating (smoothing) earnings fluctuation year after year, moving profits obtained in economic booms to poorer periods such as economic shocks [113]. Lowering earnings volatility due to managers' incentives may create a lack of transparency with less sustainable profits, which hurts financial stability. Therefore, in a nutshell, earnings management (income smoothing) is based on managers' incentives to shape accounting information.

The variable and fixed remuneration flows are crucial from the bank perspective and in crisis times because changes in corporate governance actions may lead to changes in bank strategies. If the portion of variable pay to the total remuneration of bank executives diminishes, then bank flexibility reduces too. If a bank faces a financial crisis, by nature the bank has to cut its costs or expenses to recoup its competitiveness. Costs to be cut would be loan loss impairments, dividends, credit supply to avoid unnecessary risk, and of course remuneration. In relation to the last, if bank managers are paid with variable instruments, then there is no problem, however, if they are mostly paid via fixed components, then their remuneration is not tied to bank performance and thus bank survival becomes a complicated task since compensation adjustments on fixed pay are impossible. As a response, earnings management practices are likely to occur since accounting-based incentives compensation is likely to reinforce attitudes towards building countercyclical buffers (see Table 1). Therefore, the strategies for maximizing compensation have no oneway direction (income-increasing mechanisms). "Management incentives for earnings vary depending on how accounting earnings are reflected in the incentive compensation" [114], so remuneration schemes may also drive income-decreasing accounting procedures [77]. 
Table 1. Alternative countercyclical capital policies. Adapted from ref. [115] (p. 121).

\begin{tabular}{|c|c|c|c|}
\hline Economic Cycle & Capital Rules & $\begin{array}{l}\text { Loan Loss } \\
\text { Provisioning }\end{array}$ & $\begin{array}{l}\text { Earnings Management } \\
\text { (Income Smoothing) }\end{array}$ \\
\hline Upswings & $\begin{array}{l}\text { Mandate higher } \\
\text { capital ratios }\end{array}$ & $\begin{array}{l}\text { Mandate higher } \\
\text { provisions }\end{array}$ & $\begin{array}{l}\text { Discretionary earnings } \\
\text { reduction }\end{array}$ \\
\hline Downswings & $\begin{array}{l}\text { Allow lower } \\
\text { capital ratios }\end{array}$ & $\begin{array}{l}\text { Allow lower } \\
\text { provisions }\end{array}$ & $\begin{array}{l}\text { Discretionary earnings } \\
\text { increase }\end{array}$ \\
\hline
\end{tabular}

The upper and lower limits of the remuneration guidelines may create accounting incentives for, at first, inefficient actions. For instance, in the lower bound, if managers intuit that they are just about losing great part of variable pay, they are encouraged to behave opportunistically, taking "bad risks" (risks that destroy bank value) to ensure the fixed pay (i.e., exercising call options at a fixed price). Oppositely, on the upper side, outstanding executives will probably reject "good risks" because any better performance does not imply higher remuneration anymore. Thus, they avoid the likelihood of injuring their pay or dragging their remuneration below their reference marks. In short, payment boundaries facilitate accounting incentives to manage earnings because the bank may lose business opportunities when rejecting good projects (assuming "good risk"). These are some arguments that may explain the repudiation of remuneration limits $[5,61]$, which does not mean either eliminating compensation components that motivate earnings management or boosting those that impede such opportunistic procedures [116].

The relationship between compensation schemes and earnings management practices has strongly drawn the attention of stakeholders. Shareholders, analysts, investors, and even auditors really care about earnings management. If a significant part of bank performance lies in earnings, managing it may provoke a false image of financial stability, moving earnings from future good times to the present bad moment (the income smoothing hypothesis). Therefore, "if the "true" performance of the firm is hidden, there is potential for less efficient resource allocation decisions" [117], which leads to inefficient remuneration structures. As a conclusion, even though the empirical literature has gone over it, there is still need for further analyses.

How do remuneration schemes affect earnings management behavior? Well, the evidence shows that the answer remains partially inconclusive, which is more pronounced in the banking sector because of the scarce studies. Overall, management remuneration is positively associated with earnings management and income smoothing discretionary techniques [118], but recent studies suggest that this happens when firms' characteristics are associated with moderate levels of CEO compensation and earnings management [119]. The argument is that excessive remuneration may attract shareholders' attention and raises concerns among investors about the materiality of executive and shareholder returns [120], so the use of relative income smoothing to dampen investors' beliefs is understandable since job insecurity or maybe remuneration revisions may jeopardize management positions. In fact, Li et al. [119] concluded that "when CEO compensation and earnings management are too high, such accounting manipulations are penalized (not rewarded)."

Salary, the fixed component of remuneration, restrains earnings management. It is obvious that salary is price-movement invariant; however, earnings management is costly (e.g., a litigation risk), so managers would have incentives to reduce this opportunistic behavior with an eye to lowering potential costs [116].

Broadly, the variable pay is expected to positively influence earnings management practices; however, the contrary may happen, too. First, managers receiving nil bonus adopt income-decreasing accruals, in line with taking a big bath [77,121]. Second, a positive impact on this relation is habitual; under the variable compensation system, managers have incentives to use their maximum accounting discretion to boost earnings when latent earnings may hardly reach a minimum bonus bound and push earnings downwards if performance is too poor to create incentives [114,116,121]. Third, from the income smoothing perspective, both positive and negative signs can be found. The findings of 
Shuto [121] suggested that the use of discretionary accruals to smooth income enhances the link between discretionary accruals and executive bonuses, which indicates that earnings management for bonus purposes can also be treated from the efficient contracting view. Inversely, Lee and Hwang [114] analyzed earnings management throughout using loan loss provisions and found that a higher proportion of variable compensation reduces income smoothing levels (raises earnings volatility) due to this variable pay being an incentive towards income-increasing earnings management.

Unraveling the variable payments, the empirical results are mixed. Relative to stockbased or equity-based compensation, this component primarily motivates CEOs' rent extraction through earnings management practices [105,122,123], income-increasing earnings management when financial reporting quality is low [124], and, in the case of the banking industry, when capital ratios are closer to the minimum value required by regulators [124]. Lee and Hwang [114] found no evidence of equity-based compensation acting as an effective incentive to increment bank value, but rather a motive for income-increasing earnings management. The explanation lies in that equity-linked compensation would boost banks' procyclicality [115]. Increasing earnings raises banks' capital ratio and eases lending attitudes, which consequently, as happened during the 2008 financial crisis, leads to more loan loss impairments. These losses (though future allowances) shrink credit supply, with fatal consequences for economic growth. The authors argue that in spite of the profits from decreasing earnings volatility (income smoothing) being insignificant in their sample consisting of Korean banks, because executives' average tenure is short ( 2 to 3 years), stock-based compensation might powerfully incentivize managers to use discretion to report consistent earnings. These opposing results warn about a need to design an optimal managerial compensation contract [99], which seems to be impractical.

Dhole et al. [39] advocated for the term "inside-debt" in equity-linked compensation, which mitigates earnings management and lowers levels of income smoothing (it does not mean discarding certain levels of income smoothing). The idea is that managers have a natural preference for smoothing earnings because investors perceive firms with stable earnings over time to be less risky. Hence, managers that are only equity-paid (with no debt notion) will resort to this behavior. However, when a manager is paid with a fraction of a firm's debt (and then holds inside debt), the higher the inside leverage is, the more aligned their incentives will be with those of debtholders. Therefore, managers will tend to protect inside debt value and will be more risk averse. Less risky corporate policies safeguard earnings from sharp peaks and valleys.

The link between stock-option compensation and earnings management is tricky because of the grant and exercise dates $[116,117,125]$. Managers will try to level stock price downward (upward) before (when) options are granted (exercised), thereby appreciating stock-option value. That means earnings will be managed up before exercising stock options and managed down before stock options are granted. Accordingly, performancevested stock options will be positively associated with earnings management that enhance the firm's performance [126].

In short, income smoothing practices that appear as implicit contracts are not warranted (e.g., job insecurity or compensation revision), which jeopardizes bank managers' positions. Discretionary (opportunistic) behavior to managing earnings, and thus compensation plans, is usually seen as costly (for the fixed component) and inefficient for increasing bank value (through equity-based compensation) because it encourages procyclicality [115] It could be the case that the short-terminism would be behind this: If their pay is focused on short-term incentives, despite the Guidelines, bank managers have a singular financial disincentive to engage in CSR. Therefore, CSR involvement might act as a strong incentive for bank managers to not engage in opportunistic practices that hurt financial transparency. 


\section{Unintended but Expected Consequences and Actions to Circumvent the EBA Guidelines}

\subsection{Unintended but Expected Consequences}

The EBA Guidelines sought to align risk, performance, and remuneration so as to scale down excessive risk in the banking sector. The restatement of the global corporate governance principles of financial institutions, especially remuneration policies, took place in the belief that governance failures contributed to the GFC, even though the financial trouble and consequently remuneration schemes were probably driven by an inaccurate increasing expectation for housing prices. Old rules used to reward short-terminism rather than the long-term profitability of investment projects; however, there is no clear evidence of bank compensation policy and the financial crisis. In the end, maybe because of the pressure from regulators and politicians, the EBA mainly employed two systems to address excessive risk-taking problems: (i) a risk alignment process in which variable pay must be more aligned with managers' risk appetite (e.g., payoffs in instruments, deferrals, and malus and clawback retentions), and (ii) a bonus cap.

Having said the above, we can make some predictions that the EBA Guidelines in force will result in a wide diversity of unintended consequences but expected impacts, which may produce capricious incentives and generate holes from nowhere. In fact, the data collected from the EBA reports on the identified staff remuneration structures in the EU confirmed that some predictions came true and others are likely to appear.

The bonus cap will increase fixed remuneration, will not decrease excessive risk-taking or levels of remuneration, will decrease bank competitiveness, and will reduce incentives to create value. First, in order to avoid losing wealth, a bonus cap immediately leads to an increase in the fixed component. Giving importance to the fixed pay disincentivizes bank discipline, since poor performers are not penalized and it incentivizes risky actions. In addition, higher fixed remuneration is likely to increase the risk of bank failure because of the cyclical pattern of financial services (the risk is especially transcendental in the banking sector. The variable pay of identified staff must be aligned with the bank's risk profile so that the global compensation of each bank is in line with the Risk Appetite Framework (RAF). The EBA recognizes some flexibility in their remuneration policies ([14], Whereas 8), but this is capped by the bonus cap and does not address the fact that poor performers should be negatively penalized in their variable remuneration schemes. Even though the EBA Guidelines seek to align risk and performance, at the same time they support the idea of homogenizing the RAF in EU banks (the same risk management policies). The point is that each bank's risk is assessed by the RAF, which is a tough task ex-ante, and thus another financial crisis might pop up, triggered by unforeseen accumulated risks and due to a generalized herding behavior among banks.) Second, identified staff are presumably topperforming bankers because they are considered to be material risk takers, so they are few and have highly specialized skills. If EU banks do not put competitive market remuneration on the table, they will expectedly give their most-talented managers to the competition and what it involves. Third, derived from the previous one, unregulated or less-regulated banks will absorb good managers that were constrained in highly regulated ones. In good times, their benefits are restricted, and in bad times, earnings of regulated EU banks will decrease in comparison to less-regulated banks, which leads to less flexibility, less profitability, and less bank value (less competitiveness). Losing competitiveness is particularly harmful in times of little credit grant, and low interest rates and financial margins.

The unintended consequences might create potential adverse selection problems that led to top-performing manager migration and variations in the incentive systems. For this reason, the EBA Guidelines will inexorably "allow" scope to circumvent their application. For example, fixed remuneration will be used as a variable one, which will increase or decrease according to prior-year performance. In addition, EU banks may dangerously exclude their staff from the identification process of the EBA, so those that are not considered identified staff are not tied to compensation constraints. Another example is that the EBA Guidelines do not literally prohibit the use of instruments in fixed components, 
so again we are in the dark. This practice is becoming more usual as we climb the payment brackets of HEs (see EBA reports).

\subsection{Actions to Circumvent EBA Guidelines}

\subsection{1. (Numerically) Limiting Remuneration Plans}

Being unsure of the universal solution to all the potential problems that stem from the EBA Guidelines with respect to the limit on variable-to-fixed ratio, some authors called for no regulation on (numerically) limiting remuneration practices because it confines CEOs' incentives to do their best $[5,60,61]$. Moreover, upper and lower limits can deviate identified staff (but extended to all managers) from efficient bank risk management. For example, if the fixed pay is unsensitive to performance and the identified staff faces troubles reaching the lowest levels of performance, they do not care because they will be paid for sure. Furthermore, if the identified staff has to make a risky decision that will not enhance bank performance enough to achieve variable pay, then they will forbear to make such a decision. The same happens on the upper side because if the identified staff is not going to be paid an amount that exceeds the variable cap, then they will reject profitable and good investments that could have benefitted both managers and bank value.

Figure 14 depicts three compensation schemes as a function of bank performance through different profits levels (this plot reflects a linear relation between performance via profits and remuneration amounts. However, as the EBA Guidelines do not impose any restriction, there might be another functional relation (linear, convex, or concave). To simplify the explanation, we definitely represent the linear association.) As expected, the variable pay always adds to the fixed component, except in the case of the capped system on the upper side. However, the traditional and capped remuneration structures reinforce asymmetric rewards and penalties. When an employee (no matter the charge) receives rewards for upside risk but is not penalized for downside risk, then they will take greater risks than if they faced symmetric consequences. To begin with, suppose a manager who, under the traditional scheme (green continuous line), has a base salary of EUR 400,000 but will receive $1 \%$ of any positive profit, and for whom under the capped one (red solid line) the base salary is EUR 500,000 but with a bonus of $1 \%$ over profits over EUR 10 million (assume a bonus ceiling of EUR 900,000, that is, a bonus cap of 1.8). Now, suppose the profit is expected to reach EUR 10 million, but the manager may take a chance on winning more than this amount. For example, they may make a risky bet that increases profits by an additional EUR 10 million (50\% probability) but may decrease profits by EUR 15 million (50\% probability). No doubt, under the traditional system the manager will reject it because they may win EUR 100,000 or may lose EUR 150,000; however, under the regulated system the manager will take the risk since their bonus may only increase EUR 100,000 and never fall below their base salary of EUR 500,000. Thus, lower fixed pay disincentivizes risk-taking actions.

When we looked at high-performing levels, the incentives to make risky gambles also changed with the existence of a bonus cap. Suppose now that the variable cap acts when profit levels exceed EUR 50 million, and that the expected profit is EUR 50 million. A manager would never bet on the previous project because the scenario holds under the traditional regime (the manager may win EUR 100,000 but also may lose EUR 150,000), and bonuses are capped in the regulated system (the manager may lose EUR 150,000 and will never surpass EUR 900,000).

To sum up, both opposite systems seem to be controversial. The traditional remuneration structures that are characterized by less competitive salaries and high bonus opportunities tend to create solid incentives to reject bad risks and accept good risks. Inversely, the capped remuneration regime that is defined as having above-market salaries and high bonus opportunities tend to create incentives to accept bad risks and reject good risks. In addition, when the bonus limit is achieved, managers will attempt to transfer actual realized profits to a later time because they do not gain benefit from it in the current period. A hypothetical but obvious remuneration system might be implemented and 
might solve some potential selection problems. Illustrated in Figure 4 by a dashed line, the hypothetical remuneration structure would work as follows. A manager would have a base salary of EUR 200,000 which is lower than in previous compensation schemes but higher than the rest of the bank employees because they retains more risk in their decision-making, and the variable component would be calculated as EUR 400,000 plus 1\% over profit or loss. The variable pay still adds to the fixed component, as always, but this time this manager is penalized when profits are negative. If the expected profits are zero, and the manager has to make the same gamble as before, this manager will definitely take the risk because the bonus payment will always be higher than the base salary; if unlucky, the net loss is EUR 150,000 but the total payment is EUR 250,000 (EUR 200,000 fixed plus EUR 50,000 variable). Otherwise, if fortunate, the manager will be earning EUR 500,000 (EUR 200,000 fixed plus EUR 300,000 bonus). As this hypothetical remuneration scheme does not establish any upper performance threshold as the capped regulated system does, but penalizes poor-performing managers from the optimal remuneration contracting perspective, then it provides benefits for managers. Thus, managers under the hypothetical compensation system would have incentives to accept good and bad risks in both lower and upper performance bounds, as long as the bad risky gambles do not damage the remuneration, as happens in the traditional structure.

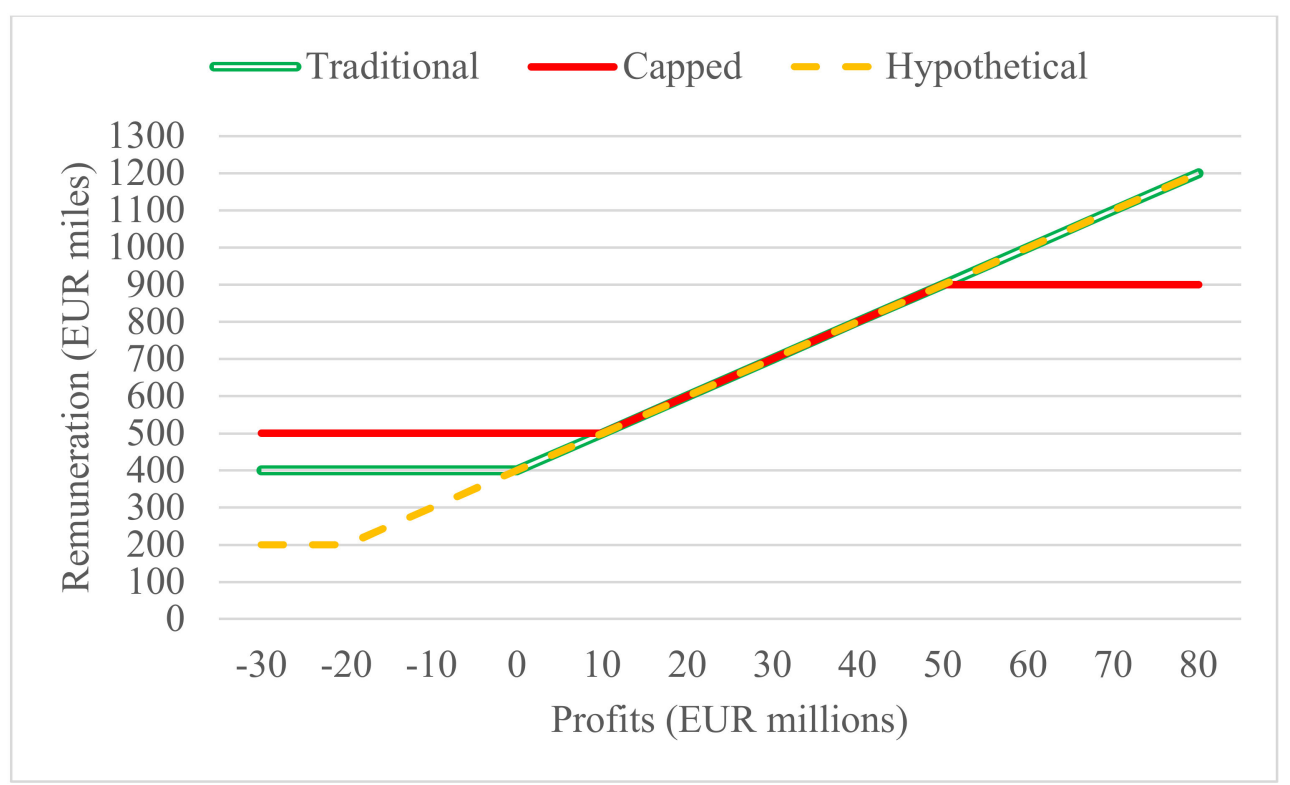

Figure 14. Traditional, capped, and hypothetical remuneration schemes. Source: own elaboration.

\subsubsection{Disclosing CSR Reporting}

As banks were primarily attributed responsibility for the financial crisis, it hurt the financial system's reputation. The lack of transparency, corporate scandals, financial and governmental bailouts, etc., eroded public trust in the industry. Among other factors, to recover the reputation, some authors argued that the outcomes of CSR reporting should be especially notorious in the banking sector, e.g., [15]

The relationship between CSR and corporate financial performance (to establish remuneration plans) is quite sophisticated, might not be direct [127], and is scarce in the banking industry; however, there exist empirical studies demonstrating that banks benefit from CSR reporting because "CSR has much larger effect on firms with bad image, such as financials" [17]. If CSR improves banks' performance, compensation plans are likely to be structured more transparently and will consider a longer time frame that reduces risk appetite from managers—-the "insurance-like" effect [24]—and accounting-based incentives compensation. 
We found multiple ways by which CSR may enhance performance. First, CSR may contribute to building differentiation approaches [128]. For instance, CSR reputational effects may occur in the long term but help banks' remuneration policy to focus on sustainable profits. Second, CSR has benefits in terms of recruitment and talent retention [129]. Overall, employee perceptions of CSR are positively associated with organizational commitment and job satisfaction. For top executives, the best-performing bank managers might be much more attracted to sustainable banks instead of those with more aggressive remuneration plans; in this sense, CSR would represent a powerful incentive to stay in the bank (reputational effect) rather than the compensation stringency that encourages moving to another one (economic effect). Third, CSR actions lead to better financing conditions [22] and credit rating improvement [130]. As mentioned earlier, the new EU remuneration policy will affect regulated EU banks more than less-regulated ones in terms of flexibility, profitability, and bank value (less competitiveness), which is pernicious in tough times (less credit supply, low interest rates, and small financial margins) because it negatively affects the whole economy (stakeholder vs. shareholder approach). In this aspect, CSR reduces agency costs due to boosted stakeholder engagement and eases information asymmetries due to increased transparency.

\section{Conclusions}

Corporate governance (CG) and corporate social responsibility (CSR) are two sides of the same coin. Both may exist at the same time, but one is always preferable, to the detriment of the other. The new EU remuneration policy in the banking industry may be good but is not the desired CG mechanism due to its economic effects. Oppositely, investing in CSR strategies may be in detriment of some remuneration components but is adequate from a reputational perspective. Economic effects are commonly associated with rewarding greedy behavior, whereas reputational effects are supposed to act like "doing it in the right way." However, there is a strong need to find the optimal position in such aspects [25].

Corporate governance issues in banks considerably differ from other non-financial companies for many reasons, especially the remuneration policy. The issue of risk-taking has frequently been the focus of attention in banking literature because although banks operate in a regulated setting, bank managers have discretion to make decisions that significantly alter the riskiness of their financial institutions, and one branch using discretion is the choice of setting up the level and composition of CEO compensation. Bank executives' remuneration has general implications for the risk-taking behavior of CEOs and for banks' performance. This is of the special concern since during financial crises moral hazard and information asymmetry problems, combined with managerial discretion, tend to be exacerbated.

With the aim of safeguarding financial stability and aligning the interests of at least stockholders with those of bank managers so as to prevent potential systemic collapses and guarantee financial system sustainability, the EU decided to regulate bank compensation policies. The result is a comprehensive set of remuneration standards that attempts to refrain excessive risk-taking by bank executives, but this time these compensation rules were amended under the regulatory rather than the supervisory perspective, so, in terms of lobbying, regulators and supervisors are not only more involved in banking activity and corporate governance but also have gained power as stakeholders. In fact, part of the compensation proposal is based on prudential oversight. Basically, among all the remuneration reforms we can highlight two main compensation mechanisms that pursue mainly aligning bank managers' risk appetite to variable payment: (i) changes in payments via instruments and deferrals, and also giving importance to retention periods (malus and clawback), and (ii) stablishing a frontier on variable compensation (the bonus cap). Many changes to the bank risk alignment process necessarily lead to reworking risk management assessment in banks. However, intricate quantitative and qualitative criteria to evaluate bank risk may generate "hidden" compensation practices that lower the transparency of 
remuneration rules and accelerate the disinterest of bank managers and owners in the aftermath of bank failures and the resultant systemic risk. With respect to the bonus cap, we might almost surely say that implementing a limit on variable pay is questionable and might provide abnormal incentives and disincentives. On the one hand, more complex compensation schemes and risk management assessment disincentivize economic actors to be involved in bank discipline. In turn, based on the data that stems from the EBA reports, increasing fixed pay also disincentivizes bank discipline since poor performers are not penalized. On the other hand, the incentive compensation may influence not only the banks' risk-taking behavior but also have an impact on their earnings management, concretely on their income smoothing practices, in spite of scarce evidence in the EU context. Although underperforming managers might take "bad risks," high performers would reject "good risks," thus delaying good decision-making that would have increased current profits for the following years. In addition, restrictions in variable remuneration introduced by the EBA Guidelines and CRD IV intensify the adverse selection problem in the EU neighborhood. For instance, EU banks will be attractive to the worst managers, whereas the best ones will move to countries where their efforts are compensated and not regulated downwards, such as the UK in the case of Brexit.

In this study, numerous unintended consequences were exposed, different actions were said to circumvent sound compensation practices regarding those who are material risk takers (identified staff), and, of course, several competing theories were postulated to enhance executive compensation as an important corporate governance mechanism. However, something is missing. The new EU remuneration policy may be gaming the system. The compensation rules are perceived to be controversial, which denotes that they might be driven by the political desire to calm down the excited public (voters) rather than rational and intelligent decisions that reduce information asymmetries and appease the potential migration of the scarce but best bank performers. Moreover, regulatory changes in the remuneration field such as binding bonus caps or shareholders' say-on-pay rights, which shows that one size does not fit all, may not reinforce the banking sector, but rather create CEO incentives to discretion.

Maybe the solution for such questionable or controversial measures would be to encourage banks to engage more in CSR practices, which probably automatically rectify or balance potential problems coming from remuneration schemes. CSR in banks reshapes transparency, corporate accountability, and public trust, as well as permits banks to retain high-quality employees and facilitates financing access. It is true that CSR disclosing reduces total and cash-based compensation of top-level bank managers but favors the use of equity-based remuneration, which is associated with long-term performance incentives that control for risk appetite in the short term. CSR must be interpreted as a reputational effect that seeks to reduce conflicts of interest among all the stakeholders. In addition, CSR implication might represent a decisive incentive for bank managers to avoid discretionary behaviors that threaten financial transparency.

Several future research questions come to light. The timeline of remuneration rules has been abrupt and long (but endless), and the FSB's proposals were drafted under an international perspective that leaves room for country-specific regulation. As the international accounting standard setters pursue the harmonization of accounting rules, it would be interesting to shed light on the convergence of the bank remuneration policy across countries, especially in the European context. Therefore, further studies should include the effect of institutional environment on the relation between remuneration structures and CEOs' incentives to discretion. Shareholders' approval to increase the variable-to-fixed pay ratio from $100 \%$ to $200 \%$ is in force, but what drives such an increment? It would also be of interest to analyze how government and prudential regulators pressure bank managers to use discretion or how they generate incentives via remuneration. This is of relevance since excessive risk-taking or capping bonus pay may generate large social costs and shocks for the whole economic system. Last but not least, CSR reporting is supposed to be a moderating factor in the new EU remuneration policy. Regarding the 
scarce banking literature on that, there is a need to examine the effect of CSR disclosure on the degree of corporate governance mechanisms (compensation in particular) in financial institutions, a sector that is powerfully monitored due to its potential social consequences. It is likely that, in the remuneration area, CSR investment (non-financial information) performs as a substitute of CG regulation (financial information).

Funding: This research received no external funding.

Institutional Review Board Statement: Not applicable.

Informed Consent Statement: Not applicable.

Data Availability Statement: Excluded.

Conflicts of Interest: The authors declare no conflict of interest.

\section{References}

1. Ferrarini, G. Understanding the role of corporate governance in financial institutions: A research agenda. European Corporate Governance Institute (ECGI)-Law Working Paper No. 347. SSRN Electron. J. 2017. [CrossRef]

2. Sandel, M.J.S. Justice: What's the Right Thing to Do; Farrar, Straus and Giroux: New York, NY, USA, 2009; Reprint.

3. Ferrarini, G.; Ungureanu, M.C. Economics, politics, and the international principles for sound compensation practices: An analysis of executive pay at European banks. Vanderbilt Law Rev. 2011, 64, 429.

4. Murphy, K.J.; Jensen, M.C. CEO Bonus Plans: And How to Fix Them. Harvard Business School NOM Unit Working Paper 12-022; Marshall School of Business Working Paper No. FBE 02-11. SSRN Electron. J. 2011. [CrossRef]

5. Murphy, K.J. Regulating banking bonuses in the European Union: A case study in unintended consequences. Eur. Financ. Manag. 2013, 19, 631-657. [CrossRef]

6. Ferrarini, G. CRD IV and the Mandatory Structure of Bankers' Pay. ECGI-Law Working Paper No. 289. SSRN Electron. J. 2015. [CrossRef]

7. Edmans, A. Performance-Based Pay for Executives Still Works. Harvard Business Review. 2016. Available online: https://hbr.org/ 2016/02/performance-based-pay-for-executives-still-works (accessed on 12 May 2021).

8. Fahlenbrach, R.; Stulz, R.M. Bank CEO incentives and the credit crisis. J. Financ. Econ. 2011, 99, 11-26. [CrossRef]

9. Ali Shah, S.Z.; Akbar, S.; Liu, J.; Liu, Z.; Cao, S. CEO compensation and banks' risk-taking during pre and post financial crisis periods. Res. Int. Bus. Financ. 2017, 42, 1489-1503. [CrossRef]

10. Beltratti, A.; Stulz, R.M. The credit crisis around the globe: Why did some banks perform better? J. Financ. Econ. 2012, 105, 1-17. [CrossRef]

11. Regulation (EU) No 1093/2010 of the European Parliament and of the Council of 24 November 2010 Establishing a European Supervisory Authority (European Banking Authority), Amending Decision No 716/2009/EC and Repealing Commission Decision 2009/78/EC. Available online: http:/ / data.europa.eu/eli/reg/2010/1093/oj (accessed on 12 May 2021).

12. Directive 2013/36/EU of the European Parliament and of the Council of 26 June 2013 on Access to the Activity of Credit Institutions and the Prudential Supervision of Credit Institutions and Investment Firms, Amending Directive 2002/87/EC and Repealing Directives 2006/48/EC and 2006/49/EC (Text with EEA Relevance). Available online: http:/ / data.europa.eu/eli/dir/2013/36/oj (accessed on 12 May 2021).

13. Regulation (EU) No 575/2013 of the European Parliament and of the Council of 26 June 2013 on Prudential Requirements for Credit Institutions and Investment Firms and Amending Regulation (EU) No 648/2012 Text with EEA Relevance. Available online: http:/ / data.europa.eu/eli/reg/2013/575/oj (accessed on 12 May 2021).

14. Directive 2019/878/EU of the European Parliament and of the Council of 20 May 2019 Amending Directive 2013/36/EU as Regards Exempted Entities, Financial Holding Companies, Mixed Financial Holding Companies, Remuneration, Supervisory Measures and Powers and Capital Conservation Measures (Text with EEA Relevance). Available online: http://data.europa.eu/ eli/dir/2019/878/oj (accessed on 12 May 2021).

15. Ruiz, B.; Esteban, Á.; Gutierrez, S. Determinants of reputation of leading Spanish financial institutions among their customers in a context of economic crisis. Bus. Res. Q. 2014, 17, 259-278. [CrossRef]

16. Chan, M.C.; Watson, J.; Woodliff, D. Corporate governance quality and CSR disclosures. J. Bus. Ethics 2014, 125, 59-73. [CrossRef]

17. Forcadell, F.J.; Aracil, E. European banks' reputation for corporate social responsibility. Corp. Soc. Responsib. Environ. Manag. 2017, 24, 1-14. [CrossRef]

18. Manes-Rossi, F.; Tiron-Tudor, A.; Nicolò, G.; Zanellato, G. Ensuring More Sustainable Reporting in Europe Using Non-Financial Disclosure-De Facto and De Jure Evidence. Sustainability 2018, 10, 1162. [CrossRef]

19. Ernst and Young. Is Your Non-Financial Performance Revealing the True Value of Your Business to Investors? Tomorrow's Investment Rules 2017. 2017. Available online: https://www.ey.com/en_gl/assurance/is-your-nonfinancial-performancerevealing-the-true-value-of-your-business (accessed on 15 April 2021).

20. Oxford Research. "Better Data Needed" on Measures of Sustainability in Business. 2017. Available online: https://www.ox.ac. uk/news/2017-04-06-better-data-needed-measures-sustainability-business (accessed on 15 April 2021). 
21. Deckop, J.R.; Merriman, K.K.; Gupta, S. The effects of CEO pay structure on corporate social performance. J. Manag. 2006, 32, 329-342. [CrossRef]

22. Cheng, B.; Ioannou, I.; Serafeim, G. Corporate social responsibility and access to finance. Strateg. Manag. J. 2014, 35, 1-23. [CrossRef]

23. Christensen, D. Corporate Accountability Reporting and High-Profile Misconduct. Account. Rev. 2016, 91, 377-399. [CrossRef]

24. Godfrey, P.; Merrill, C.; Hansen, J. The relationship between corporate social responsibility and shareholder value: An empirical test of the risk management hypothesis. Strateg. Manag. J. 2009, 30, 425-445. [CrossRef]

25. Jian, M.; Lee, K.W. CEO compensation and corporate social responsibility. J. Multinatl. Financ. Manag. 2015, 29, 46-65. [CrossRef]

26. EBA. European Banking Authority Report_Report on High Earners: 2010 and 2011 Data; EBA: London, UK, 2013.

27. EBA. European Banking Authority Report_Report on High Earners: 2012 Data; EBA: London, UK, 2013.

28. EBA. EBA Remuneration Benchmarking Report 2010 to 2012; EBA: London, UK, 2014.

29. EBA. Report on Benchmarking of Remuneration and on High Earners 2013; EBA: London, UK, 2015.

30. EBA. EBA Op-2016-05 (Report on Benchmarking of Remuneration and High Earners 2014); EBA: London, UK, 2016.

31. EBA. EBA Final Report on High Earners 2015; EBA: London, UK, 2017.

32. EBA. EBA Report on Benchmarking of Remuneration and High Earners; EBA: London, UK, 2018.

33. EBA. High Earners Report_Data as of End 2017; EBA: London, UK, 2019.

34. Bruce, A.; Buck, T.; Main, B.G. Top executive remuneration: A view from Europe. J. Manag. Stud. 2005, 42, 1493-1506. [CrossRef]

35. Dechow, P.; Ge, W.; Schrand, C. Understanding earnings quality: A review of the proxies, their determinants and their consequences. J. Account. Econ. 2010, 50, 344-401. [CrossRef]

36. Dichev, I.; Graham, R.; Harvey, C.R.; Rajgopal, S. Earnings quality: Evidence from the field. J. Account. Econ. 2013, 56, 1-33. [CrossRef]

37. Hong, Y.; Huseynov, F.; Sardarli, S.; Zhang, W. Bank earnings management and analyst coverage: Evidence from loan loss provisions. Rev. Quant. Financ. Account. 2020, 55, 29-54. [CrossRef]

38. Safta, I.L.; Achim, M.V. Quality Score on Earnings Management: Case Study on the Romanian Companies. In RSEP CONFERENCES; BC Publishing: Pender Harbour, BC, Canada, December 2020; p. 230, ISBN 978-605-06961-6-5.

39. Dhole, S.; Manchiraju, H.; Suk, I. CEO inside debt and earnings management. J. Account. Audit. Financ. 2016, 31, 515-550. [CrossRef]

40. Bebchuk, L.A.; Fried, J.M. Executive compensation as an agency problem. J. Econ. Perspect. 2003, 17, 71-92. [CrossRef]

41. Kahneman, D.; Tversky, A. Prospect theory: An analysis of decision under risk. Econometrica 1979, 47, 263-292. [CrossRef]

42. Murphy, K.J. Executive compensation: Where we are, and how we got there. In Handbook of the Economics of Finance; Elsevier: Amsterdam, The Netherlands, 2012; Volume 2, pp. 211-356.

43. García-Osma, B.; Mora, A.; Porcuna-Enguix, L. Prudential supervisors' independence and income smoothing in European banks. J. Bank. Financ. 2019, 102, 156-176. [CrossRef]

44. Treanor, J. Twenty-Four European Banks Fail Financial Stress Tests. The Guardian. 2014. Available online: https://www. theguardian.com/business/2014/oct/26/european-banks-fail-financial-stress-tests (accessed on 28 February 2021).

45. Orazalin, N. Corporate governance and corporate social responsibility (CSR) disclosure in an emerging economy: Evidence from commercial banks of Kazakhstan. Corp. Gov. Int. J. Bus. Soc. 2019, 19, 490-507. [CrossRef]

46. Murphy, K.J. Executive compensation. In Handbook of Labor Economics; Ashenfelter, O., Card, D., Eds.; Elsevier: Amsterdam, The Netherlands, 1999; Volume 3, pp. 2485-2563.

47. Turkulainen, S. Does Say-on-Pay Matter? Results from Large European Banks and the Financial Crisis (Available on Internet). Master's Thesis, Svenska Handelshögskolan, Hanken School of Economics, Helsinki, Finland, 2013.

48. Bolton, P.; Mehran, H.; Shapiro, J. Executive compensation and risk taking. Rev. Financ. 2015, 19, 2139-2181. [CrossRef]

49. Noe, T.H.; Rebello, M.J.; Wall, L.D. Managerial rents and regulatory intervention in troubled banks. J. Bank. Financ. 1996, 20, 331-350. [CrossRef]

50. Levine, R. The Corporate Governance of Banks: A Concise Discussion of Concepts and Evidence. World Bank Policy Research Working Paper 3404. 2004. Available online: http:/ / elibrary.worldbank.org/doi/book/10.1596/1813-9450-3404 (accessed on 31 December 2020).

51. John, K.; Saunders, A.; Senbet, L.W. A theory of bank regulation and management compensation. Rev. Financ. Stud. 2000, 13, 95-125. [CrossRef]

52. Chen, C.R.; Steiner, T.L.; Whyte, A.M. Does stock option-based executive compensation induce risk-taking? An analysis of the banking industry. J. Bank. Financ. 2006, 30, 915-945. [CrossRef]

53. Mayers, D.; Smith, C. Executive compensation in the life insurance industry. J. Bus. 1992, 65, 51-74. [CrossRef]

54. DeYoung, R.; Peng, E.Y.; Yan, M. Executive compensation and business policy choices at US commercial banks. J. Financ. Quant. Anal. 2013, 48, 165-196. [CrossRef]

55. Turner, A. A Regulatory Response to the Global Banking Crisis; Financial Services Authority March: London, UK, 2009.

56. Zalewska, A. A new look at regulating bankers' remuneration. Corp. Gov. Int. Rev. 2016, 24, 322-333. [CrossRef]

57. Weber, O.; Fenchel, M.; Scholz, R.W. Empirical analysis of the integration of environmental risks into the credit risk management process of European banks. Bus. Strategy Environ. 2008, 17, 149-159. [CrossRef]

58. Allen, F.; Carletti, E.; Marquez, R. Deposits and bank capital structure. J. Financ. Econ. 2015, 118, 601-619. [CrossRef] 
59. Liu, Z.; Quiet, S.; Roth, B. Banking Sector Interconnectedness: What Is It, How can We measure It And why Does It Matter? Bank Engl. Q. Bull. 2015, 55, 130-138.

60. Ferrarini, G. Regulating bankers' pay: Systemic risk, proportionality and culture. In Proceedings of the Bankers' Pay, Incentives and Regulation Conference at Bank of Portugal, Lisbon, Portugal, 29-30 September 2017.

61. Bebchuk, L.A.; Spamann, H. Regulating bankers' pay. Georget. Law J. 2009, 98, 247.

62. Lock, I.; Seele, P. Analyzing sector-specific CSR reporting: Social and environmental disclosure to investors in the chemicals and banking and insurance industry. Corp. Soc. Responsib. Environ. Manag. 2015, 22, 113-128. [CrossRef]

63. Lentner, C.; Szegedi, K.; Tatay, T. Social Responsibility in the Operation of Central Banks. Financ. Econ. Rev. 2015, 16, 64-85. [CrossRef]

64. Loew, E.; Klein, D.; Pavicevac, A. Corporate Social Responsibility Reports of European Banks—An Empirical Analysis of the Disclosure Quality and its Determinants; Working Paper 19/03; European Banking Institute: Frankurt, Germany, 2019.

65. Shen, C.H.; Wu, M.W.; Chen, T.H.; Fang, H. To engage or not to engage in corporate social responsibility: Empirical evidence from global banking sector. Econ. Model. 2016, 55, 207-225. [CrossRef]

66. Directive 2014/95/EU of the European Parliament and of the Council of 22 October 2014 Amending Directive 2013/34/EU as Regards Disclosure of Non-Financial and Diversity Information by Certain Large Undertakings and Groups (Text with EEA Relevance). Available online: http:/ / data.europa.eu/eli/dir/2014/95/oj (accessed on 12 May 2021).

67. Karim, K.; Lee, E.; Suh, S. Corporate social responsibility and CEO compensation structure. Adv. Account. 2018, 40, 27-41. [CrossRef]

68. Graafland, J.; Kaptein, M.; Mazereeuw-van der Duijn Schouten, C. Motives of Socially Responsible Business Conduct. Center Discussion Paper Series No. 2010-74. SSRN Electron. J. 2010. [CrossRef]

69. Cai, Y.; Jo, H.; Pan, C. Vice or virtue? The impact of corporate social responsibility on executive compensation. J. Bus. Ethics 2011, 108, 159-173. [CrossRef]

70. Mahoney, L.S.; Thorn, L. An examination of the structure of executive compensation and corporate social responsibility: A Canadian investigation. J. Bus. Ethics 2006, 69, 149-162. [CrossRef]

71. Jensen, M.; Meckling, W. Theory of the firm: Managerial behavior, agency costs, and ownership structure. J. Financ. Econ. 1976, 3, 305-360. [CrossRef]

72. Marques, L.B.; Oppers, S.E. Risk-Taking by Banks: The Role of Governance and Executive Pay. In IMF Global Financial Stability Report: Risk Taking, Liquidity, and Shadow Banking-Curing Excess While Promoting Growth; International Monetary Fund: Washington, DC, USA, 2014.

73. Boeri, T.; Lucifora, C.; Murphy, K. Executive Remuneration and Employee Performance-Related Pay; Oxford University Press: Oxford, UK, 2013.

74. Rajgopal, S.; Shevlin, T. Empirical evidence on the relation between stock option compensation and risk taking. J. Account. Econ. 2002, 33, 145-171. [CrossRef]

75. Angeli, M.; Gitay, S. Bonus Regulation: Aligning Reward with Risk in the Banking Sector; Bank of England Quarterly Bulletin, Q4: London, UK, 2015.

76. EBA/RTS/2014/02. EBA FINAL Draft Regulatory Technical Standards on Classes of Instruments that Are Appropriate to be Used for the Purposes of Variable Remuneration Under Article 94(2) of Directive 2013/36/EU. London, UK. 2014. Available online: https: / / www.eba.europa.eu/ (accessed on 31 December 2020).

77. Healy, P.M. The effect of bonus schemes on accounting decisions. J. Account. Econ. 1985, 7, 85-107. [CrossRef]

78. Short, J. Are We Wasting Time with the Corporate Social Performance-Financial Performance Link. In Proceedings of the National Meetings of the Academy of Management, New Orleans, LO, USA, 6-11 August 2004.

79. Clarke, D.C. The independent director in Chinese corporate governance. Del. J. Corp. Law 2006, 31, 125-228.

80. Ye, K. Independent director cash compensation and earnings management. J. Account. Public Policy 2014, 33, 391-400. [CrossRef]

81. Adams, R.B.; Ferreira, D. Do directors perform for pay? J. Account. Econ. 2008, 46, 154-171. [CrossRef]

82. Brick, I.E.; Palmon, O.; Wald, J.K. CEO compensation, director compensation, and firm performance: Evidence of cronyism? J. Corp. Financ. 2006, 12, 403-423. [CrossRef]

83. Tirole, J. Corporate Governance. Econometrica 2001, 69, 1-35. [CrossRef]

84. Frederick, S.; Loewenstein, G.; O'donoghue, T. Time discounting and time preference: A critical review. J. Econ. Lit. 2002, 40, 351-401. [CrossRef]

85. Johnston, A. Preventing the Next Financial Crisis? Regulating Bankers' Pay in Europe. J. Law Soc. 2014, 41, 6-27. [CrossRef]

86. Calomiris, C.W.; Jaremski, M. Deposit insurance: Theories and facts. Annu. Rev. Financ. Econ. 2016, 8, 97-120. [CrossRef]

87. De Andrés, P.; Reig, R.; Vallelado, E. European banks' executive remuneration under the new European Union regulation. J. Econ. Policy Reform 2019, 22, 208-225. [CrossRef]

88. James, E.H. In the wake of the financial crisis: Rebuilding the image of the finance industry through trust. J. Financ. Transform. 2009, 27, 37-41.

89. Jizi, M.; Salama, A.; Dixon, R.; Stratling, R. Corporate governance and corporate social responsibility disclosure: Evidence from the US banking sector. J. Bus. Ethics 2014, 125, 601-615. [CrossRef]

90. Larosière, J.D. Report of the High-Level Group on Financial Supervision in the EU; European Commission: Brussels, Belgium, 2009. 
91. Bouvatier, V.; Lepetit, L.; Strobel, F. Bank income smoothing, ownership con- centration and the regulatory environment. J. Bank. Financ. 2014, 41, 253-270. [CrossRef]

92. Borlea, S.N.; Achim, M.V.; Mare, C. Board characteristics and firm performances in emerging economies. Lessons from Romania. Econ. Res. Ekon. Istraživanja 2017, 30, 55-75. [CrossRef]

93. Gebhardt, G.; Novotny-Farkas, Z. Mandatory IFRS adoption and accounting quality of European banks. J. Bus. Financ. Account. 2011, 38, 289-333. [CrossRef]

94. Haldane, A.G. Control rights (and wrongs). Econ. Aff. 2012, 32, 47-58. [CrossRef]

95. Ghoul, S.E.; Guedhami, O.; Kwok, C.C.Y.; Mishra, D.R. Does Corporate Social Responsibility Affect the Cost of Capital? J. Bank. Financ. 2011, 35, 2388-2406. [CrossRef]

96. Global Reporting Initiative (GRI). G4 Sustainability Reporting Guidelines-Frequently Asked Questions. 2015. Available online: https://www.globalreporting.org/how-to-use-the-gri-standards/questions-and-answers/ (accessed on 15 April 2021).

97. ElAlfy, A.; Weber, O. Corporate Sustainability Reporting: The Case of the Banking Industry; CIGI Papers No. 211; Centre for International and Government Innovation: Waterloo, ON, Canada, 2019.

98. Doucouliagos, H.; Haman, J.; Askary, S. Directors' remuneration and performance in Australian banking. Corp. Gov. Int. Rev. 2007, 15, 1363-1383. [CrossRef]

99. Dutta, S.; Fan, Q. Equilibrium earnings management and managerial compensation in a multiperiod agency setting. Rev. Account. Stud. 2014, 19, 1047-1077. [CrossRef]

100. Tahir, M.; Ibrahim, S.; Nurullah, M. Getting compensation right-The choice of performance measures in CEO bonus contracts and earnings management. Br. Account. Rev. 2019, 51, 148-169. [CrossRef]

101. Conyon, M.J.; Sadler, G. Shareholder voting and directors' remuneration report legislation: Say on pay in the UK. Corp. Gov. Int. Review. 2010, 18, 296-312. [CrossRef]

102. Conyon, M.J. Shareholder Dissent on Say-on-Pay and CEO Compensation. SSRN Electron. J. 2016. [CrossRef]

103. Fisch, J.; Palia, D.; Solomon, S.D. Is Say on Pay All about Pay: The Impact of Firm Performance. Harv. Bus. Law Rev. 2018, 8, 101.

104. Thanassoulis, J. The case for intervening in bankers' pay. J. Financ. 2012, 67, 849-895. [CrossRef]

105. Almadi, M.; Lazic, P. CEO incentive compensation and earnings management: The implications of institutions and governance systems. Manag. Decis. 2016, 54, 2447-2461. [CrossRef]

106. Carletti, E.; Vives, X. Regulation and competition policy in the banking sector. In Competition Policy in Europe; Fifty Years of the Treaty of Rome; Oxford University Press: Oxford, UK, 2009; pp. 260-283.

107. Calomiris, C.W.; Haber, S.H. Fragile by Design: The Political Origin of Banking Crises and Scarce Credit; Mokyr, J., Ed.; The Princeton Economic History of the Western World: Princeton, NJ, USA, 2014.

108. Barth, J.R.; Caprio, G., Jr.; Levine, R. Rethinking Bank Regulation: Till Angels Govern; Cambridge University Press: Cambridge, $\mathrm{UK}, 2006$.

109. Brown, C.O.; Dinc, S. The Politics of Bank Failures: Evidence from Emerging Markets. Q. J. Econ. 2005, 120, 1413-1444. [CrossRef]

110. Tversky, A.; Kahneman, D. Advances in prospect theory: Cumulative representation of uncertainty. J. Risk Uncertain. 1992, 5, 297-323. [CrossRef]

111. Healy, P.M.; Wahlen, J.M. A review of the earnings management literature and its implications for standard setting. Account. Horiz. 1999, 13, 365-383. [CrossRef]

112. Guidry, F.; Leone, A.J.; Rock, S. Earnings-based bonus plans and earnings management by business-unit managers. J. Account. Econ. 1999, 26, 113-142. [CrossRef]

113. Copeland, R.M. Income smoothing. J. Account. Res. 1968, 101-116. [CrossRef]

114. Lee, M.; Hwang, I.T. The Effect of the Compensation System on Earnings Management and Sustainability: Evidence from Korea Banks. Sustainability 2019, 11, 3165. [CrossRef]

115. Koch, T.W.; Waggoner, D.F.; Wall, L.D. Incentive compensation, accounting discretion and bank capital. J. Econ. Bus. 2018, 95, 119-140. [CrossRef]

116. Gao, P.; Shrieves, R.E. Earnings Management and Executive Compensation: A Case of Overdose of Option and Underdose of Salary; University of Tennessee: Knoxville, TN, USA, 2002.

117. Meek, G.K.; Rao, R.P.; Skousen, C.J. Evidence on factors affecting the relationship between CEO stock option compensation and earnings management. Rev. Account. Financ. 2007, 6, 304-323. [CrossRef]

118. Godfrey, J.M.; Jones, K.L. Political cost influences on income smoothing via extraordinary item classification. Account. Financ. 1999, 39, 229-253. [CrossRef]

119. Li, L.; Holmes, M.J.; Lee, B.S. The asymmetric relationship between executive earnings management and compensation: A panel threshold regression approach. Appl. Econ. 2016, 48, 5525-5545. [CrossRef]

120. Fudenberg, D.; Tirole, J. A theory of income and dividend smoothing based on incumbency rents. J. Political Econ. 1995, 103, 75-93. [CrossRef]

121. Shuto, A. Executive compensation and earnings management: Empirical evidence from Japan. J. Int. Account. Audit. Tax. 2007, 16, 1-26. [CrossRef]

122. Bergstresser, D.; Philippon, T. CEO incentives and earnings management. J. Financ. Econ. 2006, 80, 511-529. [CrossRef]

123. Laux, C.; Laux, V. Board committees, CEO compensation, and earnings management. Account. Rev. 2009, 84, 869-891. [CrossRef] 
124. Chen, C.-Y.; Li, M.-Y. Executive Equity Compensation and Earnings Management: A Quantile Regression Approach. Proceedings of the Annual Conference on Pacific Basin Economics, Finance, Accounting, and Management. Research Collection School of Accountancy. 2011. Available online: http://ink.library.smu.edu.sg/soa_research/979 (accessed on 15 March 2021).

125. Baker, T.; Collins, D.; Reitenga, A. Stock option compensation and earnings management incentives. J. Account. Audit. Financ. 2003, 18, 557-582. [CrossRef]

126. Kuang, Y.F. Performance-vested stock options and earnings management. J. Bus. Financ. Account. 2008, 35, 1049-1078. [CrossRef]

127. Zhu, Y.; Sun, L.; Leung, A.S. Corporate social responsibility, firm reputation, and firm performance: The role of ethical leadership. Asia Pac. J. Manag. 2014, 31, 925-947. [CrossRef]

128. Lii, Y.; Lee, M. Doing right leads to doing well: When the type of CSR and reputation interact to affect consumer evaluations of the firm. J. Bus. Ethics 2012, 105, 69-81. [CrossRef]

129. Glavas, A.; Kelley, K. The effects of perceived corporate social responsibility on employee attitudes. Bus. Ethics Q. 2014, 24, 165-202. [CrossRef]

130. Jiraporn, P.; Jiraporn, N.; Boeprasert, A.; Chang, K. Does corporate social responsibility (CSR) improve credit ratings? Evid. Geogr. Identif. Financ. Manag. 2014, 43, 505-531. [CrossRef] 